\title{
Electron spin resonance dating of the culminant allostratigraphic unit of the Mondego and Lower Tejo Cenozoic basins (W Iberia), which predates fluvial incision into the basin-fill sediments
}

\author{
Margarida P. Gouveia ${ }^{\mathrm{a}, *}$, Pedro P. Cunha ${ }^{\mathrm{a}}$, Christophe Falguères ${ }^{\mathrm{b}}$, Pierre Voinchet $^{\mathrm{b}}$, \\ António A. Martins ${ }^{c}$, Jean-Jacques Bahain ${ }^{\mathrm{b}}$, Alcides Pereira ${ }^{\mathrm{d}}$ \\ ${ }^{a}$ MARE - Marine and Environmental Sciences Centre, Department of Earth Sciences, University of Coimbra, Rua Sílvio Lima, Univ. Coimbra - Pólo II, $3030-790$ Coimbra, \\ Portugal \\ ${ }^{\mathrm{b}}$ HNHP UMR 7194 - Histoire Naturelle de l'Homme Préhistorique, MNHN-CNRS-UPVD, Département Homme et Environnement, Muséum National d'Histoire Naturelle, 1 \\ rue René Panhard, 75013 Paris, France \\ ${ }^{\mathrm{c}}$ ICT - Institute of Earth Sciences, Department of Geosciences, University of Évora, Rua Romão Ramalho, 59, 7000-671 Évora, Portugal \\ ${ }^{\mathrm{d}}$ CITEUC - Centre for Earth and Space Research, Department of Earth Sciences, University of Coimbra, Rua Sílvio Lima, Univ. Coimbra - Pólo II, $3030-790$ Coimbra, \\ Portugal
}

\section{A R T I C L E I N F O}

\section{Keywords:}

ESR dating

Transition infill-dissection

Pliocene

Pleistocene

Western Iberia

\begin{abstract}
A B S T R A C T
The Cenozoic basins of western Iberia have a culminant allostratigraphic unit (designated UBS13), which records the beginning of Atlantic drainage and predates the fluvial incision that led to the development of the present drainage networks. However, the available numerical dating is quite limited and mainly restricted to the lowerlevel terrace deposits. Therefore, this study uses for the first time the electron spin resonance (ESR) method to date this culminant unit in the Mondego and Lower Tejo Cenozoic basins of Portugal. The depositional age of this unit is supposed to lie between $\sim 3.7 \mathrm{Ma}$ (basal deposits) and $\sim 1.8 \mathrm{Ma}$ (uppermost deposits). The Al-centre provided reliable ESR data, but the dates obtained by using the Ti-Li centre clearly underestimate the burial ages. With reference to the existing independent dating of the Vale Farpado site (3.7-3.6 Ma) at the lowermost basal level of the UBS13 deposits, the ESR (Al-centre) ages of 3.0 to 2.3 Ma obtained for the UBS13 basal and middle deposits give reliable estimates of the burial age. The ESR ages (Al-centre) obtained for the UBS13 uppermost deposits indicate a probable age of $\sim 1.8 \mathrm{Ma}$. Thus, these results are of international significance, in that they constitutes the first numerical ages obtained for the uppermost levels of the Cenozoic basin-fills of western Iberia, which predate the fluvial incision that took place in response to lower Quaternary base levels.
\end{abstract}

\section{Introduction}

In the near future, the forecast of an increased intensity of global warming raises concern about sea-level rise, as the primary outcome of the melting process of large fractions of Greenland and Antarctic ice sheets. Despite the apparent novelty of this situation, there have been previous warming periods in recent geological time, in particular at the beginning of the Pleistocene interglacial periods (Rocoux et al., 2006; Jiménez-Moreno et al., 2010, 2019), which offer guidance for understanding the magnitude of a possible sea-level rise in the future. In this context, the Iberian Western Margin preserves a good record of glacial-interglacial climate change (e.g. Pedoja et al., 2018). Furthermore, the Pliocene represents the final shift from warmer paleoclimates to the glacial-interglacial episodes of the Quaternary (e.g. Loutre and Berger, 2003; Dowsett et al., 2012) and the Western Iberian Margin is an excellent natural laboratory for exploring coastal to fluvial Earth systems.

Climatically, the Pliocene can be divided into two periods, Early (Zanclean) and Late (Piacenzian), the first with the warmest temperatures, and subsequent climatic cooling during the Pleistocene (e.g. Haywood et al., 2011). In general, the Pliocene world was similar in many respects to what models estimate that Earth could become in the future (Jansen et al., 2007; Haywood et al., 2011; Raymo et al., 2011). Moreover, the Pliocene is sufficiently recent for the continents and ocean basins to have nearly reached their present geographic configuration.

A major research theme of global-scale reconstruction has been

\footnotetext{
* Corresponding author.

E-mail addresses: mariamporto@gmail.com (M.P. Gouveia), pcunha@dct.uc.pt (P.P. Cunha), christophe.falgueres@mnhn.fr (C. Falguères), pierre.voinchet@mnhn.fr (P. Voinchet), aam@uevora.pt (A.A. Martins), bahain@mnhn.fr (J.-J. Bahain), apereira@dct.uc.pt (A. Pereira).
} 


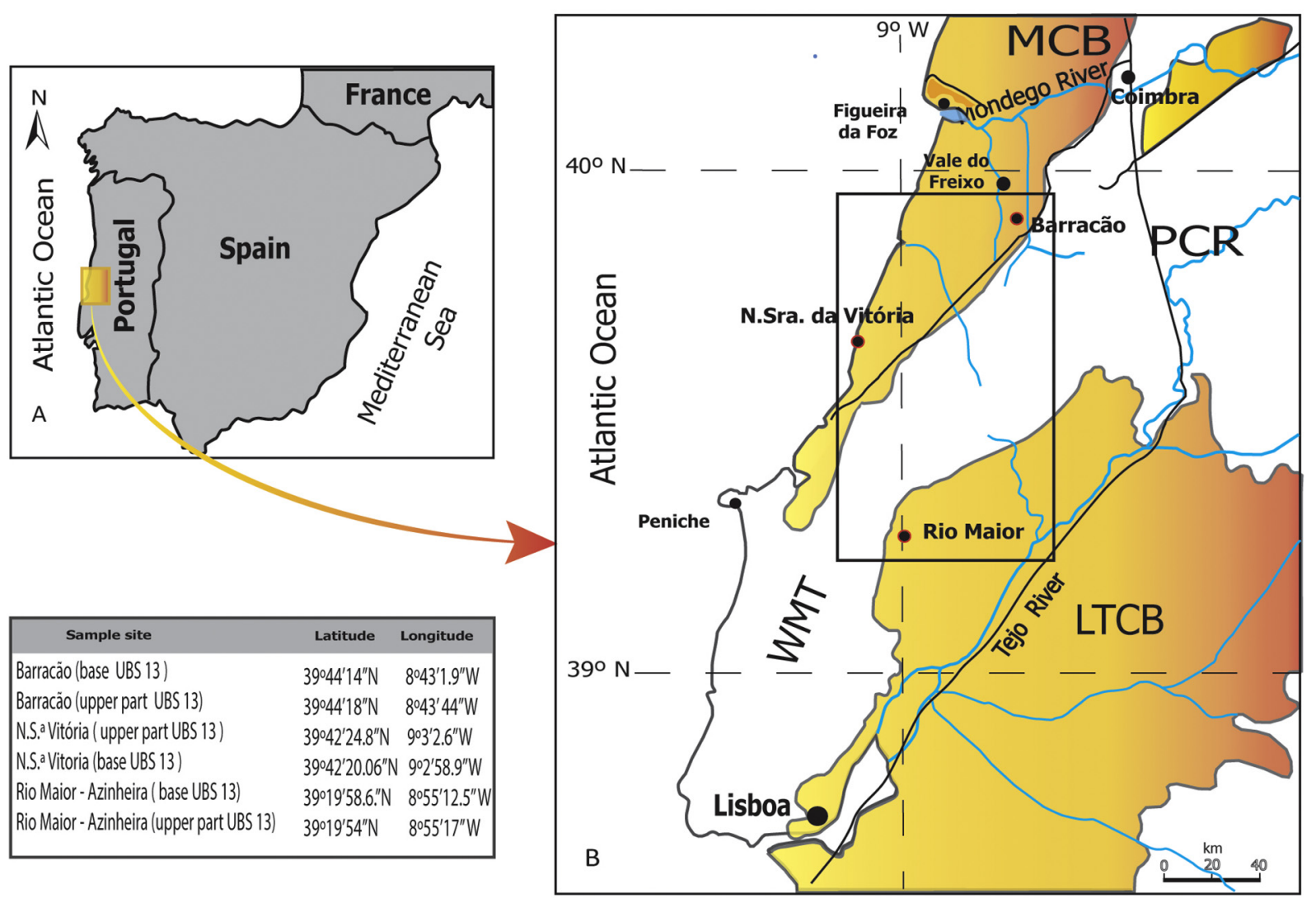

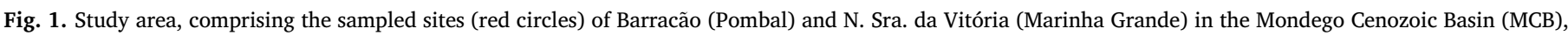

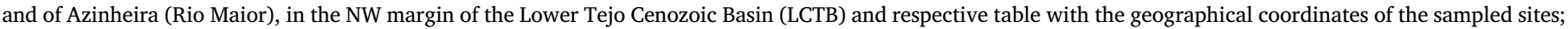

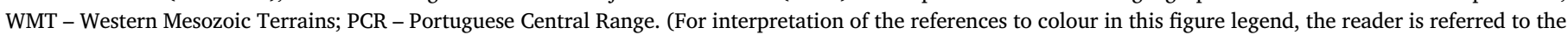
web version of this article.)

focused on atmosphere-ocean interaction (Lisiecki and Raymo, 2005; Rocoux et al., 2006; Rodrigues et al., 2011). However, terrestrial records also offer promising alternative proxy data, providing relevant insights into understanding of the climatic and environmental changes that occurred during the Pliocene and Pleistocene (e.g. Rodrigues et al., 2011; Salzman et al., 2013; Rohling et al., 2014; Haywood et al., 2016; Panitz et al., 2016).

The location of the Cenozoic basins of western Iberia, near the East Atlantic margin $\left(\sim 40^{\circ} \mathrm{N}, 9^{\circ} \mathrm{W}\right)$, has a significant geological importance, as it allows the use of detailed sedimentary and biostratigraphic information, critical to the study of the major tectonic, climatic and eustatic events affecting the North Atlantic margin (Martín et al., 2009; Cunha et al., 2016). Western Iberia, due its geographic position, transitional between Northern Europe and Africa, and part of the Western Mediterranean environment, is a strategic area for the analysis of the processes associated with climate variability in different regional contexts.

In the Mondego and Lower Tejo Cenozoic basins, located in Portugal (Fig. 1), the allostratigraphic unit UBS13 (uppermost Zanclean - Gelasian; Cunha, 1992a, b) is the culminant unit of the sedimentary infill and consists of marine and continental sediments (e.g. Cunha et al., 1993; Pais et al., 2012; Cunha, 2019).

The base of UBS13 is a sedimentary discordance recorded in the Iberian Cenozoic basins and resulting from a tectonic phase at $\sim 3.7 \mathrm{Ma}$ (e.g. Cunha, 1992b; Calvo et al., 1993). The top of the UBS13 unit records the reversal of the sedimentary basin infilling and the beginning of fluvial incision (Cunha, 2019). The later incision stage is recorded by Pleistocene marine and fluvial terraces that are inset below the culminant surface of the UBS13 unit. Notwithstanding this, the chronostratigraphic framework for the UBS13 unit needs to be significantly improved. For the basal deposits of UBS13, the chronological data are supported by biostratigraphy based on calcareous nannofossils and molluscan assemblages from the Vale do Freixo site (near Carnide; Mondego Cenozoic Basin; Fig. 1), which indicate for this basal level an age of $\sim 3.65 \mathrm{Ma}$ (Cachão, 1989, 1990; Diniz et al., 2016). However, some pectinid shells from the same level, analyzed for ${ }^{87} \mathrm{Sr} /{ }^{86} \mathrm{Sr}$ isotopes, were dated to $3.79 \pm 0.27 \mathrm{Ma}$ and $4.38 \pm 0.27 \mathrm{Ma}$ (Silva, 2001, 2010). Moreover, in the Mondego and Lower Tejo Cenozoic basins are other sites containing the lowermost deposits providing mollusc shells ascribed to the Late Pliocene, such as N. Sra. da Vitória, Águas Santas (Choffat, 1889, 1903; Dollfus and Cotter, 1909; Cachão, 1989; Silva, 2001), Alfeite (Dolfus and Cotter, 1909), Fonte da Telha (Zbyszewsky, 1943), Carnide, Vale Cabra and Vale Farpado (Teixeira and Zbyszewsky, 1951; Rocha and Ferreira, 1953). In contrast, the age of the UBS13 uppermost deposits is supported only by (i) a palaeomagnetic study at Rio Maior (Lower Tejo Cenozoic Basin, which observed a major magnetostratigraphic reversal attributed to the Gauss-Matuyama boundary (2.58 Ma) at a stratigraphic level located $\sim 17 \mathrm{~m}$ below the top surface of the unit (Diniz and Mörner, 1995), and (ii) a probable age estimate of $\sim 1.8 \mathrm{Ma}$, obtained by extrapolation based on dated terrace staircases of the Lower Tejo and Mondego Cenozoic basins (Cunha et al., 2016). Cosmogenic (burial isochron) dating was also used to date the UBS13 unit in the Alvalade Cenozoic Basin, namely at Vila Nova de Mil Fontes ( 4 Ma; Ressurreição, 2018) and Sagres promontory ( $\sim 1.8 \mathrm{Ma}$; Figueiredo, 2014). Palynological studies also indicated a latest Zanclean to Gelasian age for the aggradation interval of UBS13 (Diniz, 1984; Vieira, 2009, Vieira et al., 2018).

The present work uses ESR dating of samples collected from the UBS13 unit, being the first attempt using this palaeodosimetric method 
for Late Pliocene to Gelasian deposits in Iberia. In Portugal, a single previous study used ESR to obtain a date of $900 \mathrm{ka}$ for the first (highest) terrace of the Lower Tejo River (Rosina et al., 2014). In Spain, again using ESR, the oldest terraces of the Ebro and Duero basins were dated to 1.3 Ma (Duval et al., 2015) and 1.14 Ma (Moreno et al., 2012), respectively.

The aims of this study are (i) to obtain ESR ages from the basal and uppermost sedimentary deposits of the allostratigraphic unit UBS13 in selected outcrops of the Mondego and Lower Tejo Cenozoic basins (in coastal and inland sectors) and (ii) to provide an ESR age for the beginning of fluvial incision.

\section{Geological setting}

During Lutetian times, in western Iberia, the Pyrenean orogeny began to generate the Mondego and Lower Tejo Cenozoic basins (e.g. Cunha, 1992a, 2019; Pais, 1992). Until the middle Tortonian ( $\sim 9.6 \mathrm{Ma})$, their evolution was marked by a gradual erosion of the Hesperian Massif, under continuous tectonic deformation and climatic conditions (semi-arid to subtropical climate with long dry season) that favoured the planation of the basement and the transport of feldspathic sands into the basins. During the late Miocene and most of the Zanclean the climate was hot with strong inter-seasonal amplitude and sedimentation was expressed by endorheic conditions and alluvial fans at the scarp feet of active faults (Cunha et al., 2019).

According to the records of fossil pollen content of the UBS13 sedimentary succession (Diniz, 1984, 2003; Vieira, 2009, Vieira et al., 2018; Pais et al., 2010; Diniz et al., 2016), a hot and wet climate prevailed during the latest Zanclean and the Piacenzian, with little seasonal contrast and precipitation probably in excess of $1000 \mathrm{~mm}$ per year in the less hot seasons. The pollen content in the upper part of the succession records a transition to a less forested environment and cooler climate during the Gelasian.

A marine incursion took place on the Atlantic coast of Portugal during the latest Zanclean - earliest Piacenzian, reaching inland areas located $\sim 28 \mathrm{~km}$ from the present coastline (e.g. Zbyszewski, 1949; Teixeira and Zbyszewski, 1951, 1954; Teixeira, 1979; Ferreira, 1981; Cunha, 1992a, 1992b; Cunha, 2019; Cunha et al., 1993; Ramos, 2008). This incursion was related to a high eustatic sea-level of $40-60 \mathrm{~m}$ (Dowsett et al., 1996) or 20-25 m (Miller et al., 2005, 2011) above present. During the following sea-level highstand, a large shallow sandy littoral zone developed, with fan-delta environments having an abundant siliciclastic sediment supply. In the Mondego and Lower Tejo Cenozoic basins, the main fluvial drainage axes became the ancestors of the modern rivers (Pais et al., 2012).

According to (Cunha et al. 2012, 2016), fluvial incision into the basin sediments began by $\sim 1.8 \mathrm{Ma}$ (end of Gelasian) when the climate became colder, with the regional tectonic uplift due to Iberia-Africa convergence (de Vicente et al., 2011, 2018; Cunha et al., 2012, 2016) and the eustasy (sea-level lowering) the primal determinants for the progressive evolution of the river systems draining to the Atlantic Ocean: strong incision, regressive erosion and stream piracy.

Onshore, the Mondego Cenozoic Basin is $\sim 180 \mathrm{~km}$ wide and extends inland $\sim 90 \mathrm{~km}$ (Fig. 1). In general, the UBS13 unit is well represented (Fig. 2) with a thickness of $\sim 20 \mathrm{~m}$ south of the Mondego River, although syn-depositional tectonic activity has caused local tilting, vertical fault displacement and the development of small fault-bounded sub-basins in which this unit can reach a thickness of 40-70 m.

In this region, the UBS13 unit is generally composed of shallowmarine, near-shore and continental sediments, documenting a regressive succession that comprises three lithostratigraphic sub-units (Barbosa, 1983; Cachão, 1989; Cunha, 1992a; Cunha et al., 1993, 2009; Ramos and Cunha, 2004) (Fig. 3):

1. Carnide Formation, consisting of a basal level rich in bioclasts, followed by fine to very fine yellowish silty micaceous sand, representative of a marine sublitoral environment; some levels of well rounded pebbles are interbedded with low-angle, planar-stratified coarse sands, of beach-face origin.

2. Roussa Formation, composed of medium to fine whitish sands, with large-scale planar or trough cross stratification, representing a deltaic environment.

3. Barracão Group, consisting of clays intercalated with sands (palustrine) to sands and gravels (upper fan-delta and fluvial environments) (Cunha et al., 1993; Ramos, 2008; Pais et al., 2012; Dinis and Oliveira, 2016). The Barracão Group has a tabular geometry, its thickness increasing gradually towards the west. Syn-depositional tectonic activity seems to have been responsible for local variations in thickness $(40-70 \mathrm{~m})$ and facies.

The Lower Tejo Cenozoic Basin occupies an area $\sim 80 \mathrm{~km}$ wide and approximately $260 \mathrm{~km}$ long, between Setúbal Peninsula and the Spanish border. The UBS13 unit is documented throughout the basin and also covering areas of Palaeozoic basement (Fig. 4) that mark the separation from the Madrid Cenozoic Basin (Cunha, 2019). The UBS13 unit here comprises several major lithostratigraphic subdivisions (e.g. Pais, 1981; Azevêdo, 1982; Barbosa, 1995; Cunha, 1996; Pais et al., 2012): the Santa Marta sands (delta front), Belverde conglomerate (delta plain) and Ulme sands/Serra de Almeirim conglomerates/Falagueira Formation (fluvial).

\section{Materials and methods}

\subsection{Field work}

Selected outcrops of the UBS13 unit were studied in detail in order to improve the characterization of the local stratigraphy and sedimentology. Fieldwork included stratigraphic logging and sedimentological characterization of the sediments in order to obtain data on the depositional facies, including sediment colour, texture and clast-lithological characterization.

\subsubsection{The Barracão site}

At a claypit $\left(39^{\circ} 49^{\prime} \mathrm{N} ; 8^{\circ} 43^{\prime} \mathrm{W}\right)$ located near the village of Barracão, the culminant basin-fill unit UBS13 is formed by a succession of continental deposits: overlying Miocene clays, an alternation of 0.5-1.0 m thick beds of sand and silts (sometimes organic and containing fossil timber) grade upwards to fluvial gravels (Fig. 5; Fig. 6 A, B).

Locally, the base of the unit comprises a sequence of very coarse sands, gravels and grey silts with a thickness of $\sim 3 \mathrm{~m}$. Immediately above is a thin layer of greyish silt passing upwards into medium to fine yellow sands $\sim 4 \mathrm{~m}$ thick. This well-sorted sand is interspersed with layers of coarser sand. The sequence continues with an alternation of coarse-grained yellow sands with concave cross structures $(\mathrm{St})$ and thin dark grey silts. In the middle part, the sands have a larger clay fraction and are better sorted. In the upper part, whitish sands and gravels include round and angular quartz and quartzite clasts. Two samples were collected for ESR dating: sample BAR1, from $5.5 \mathrm{~m}$ above the base of the UBS13 unit, and sample BAR2, from the top of the local succession, probably from a terrace (surface at $83 \mathrm{~m}$ above sea level (a.s.l.)) (Fig. 5). In this area, the culminant surface (top of the UBS13 unit) is at 126-127 m a.s.l.

\subsubsection{The N. Sra. da Vitória site}

At N. Sra. da Victória beach $\left(39^{\circ} 42^{\prime} \mathrm{N} ; 9^{\circ} 3^{\prime} \mathrm{W}\right)$, the UBS13 unit contacts directly with upper Triassic to Hettangian evaporitic marls and silty clays, having been significantly folded and fractured (Choffat, 1889; Cachão, 1989; Ribeiro, 1998; Ribeiro and Cabral, 1998; Ramos, 2008; Cabral et al., 2018). The Carnide and Roussa formations are folded into a broad syncline, which is truncated in the upper part of the beach cliffs (at a height of $\sim 25 \mathrm{~m}$ a.s.l.) by a Late Pleistocene (dated as $\sim 40-30 \mathrm{ka}$ ) unit of aeolian sands (Benedetti et al., 2009), followed by a 


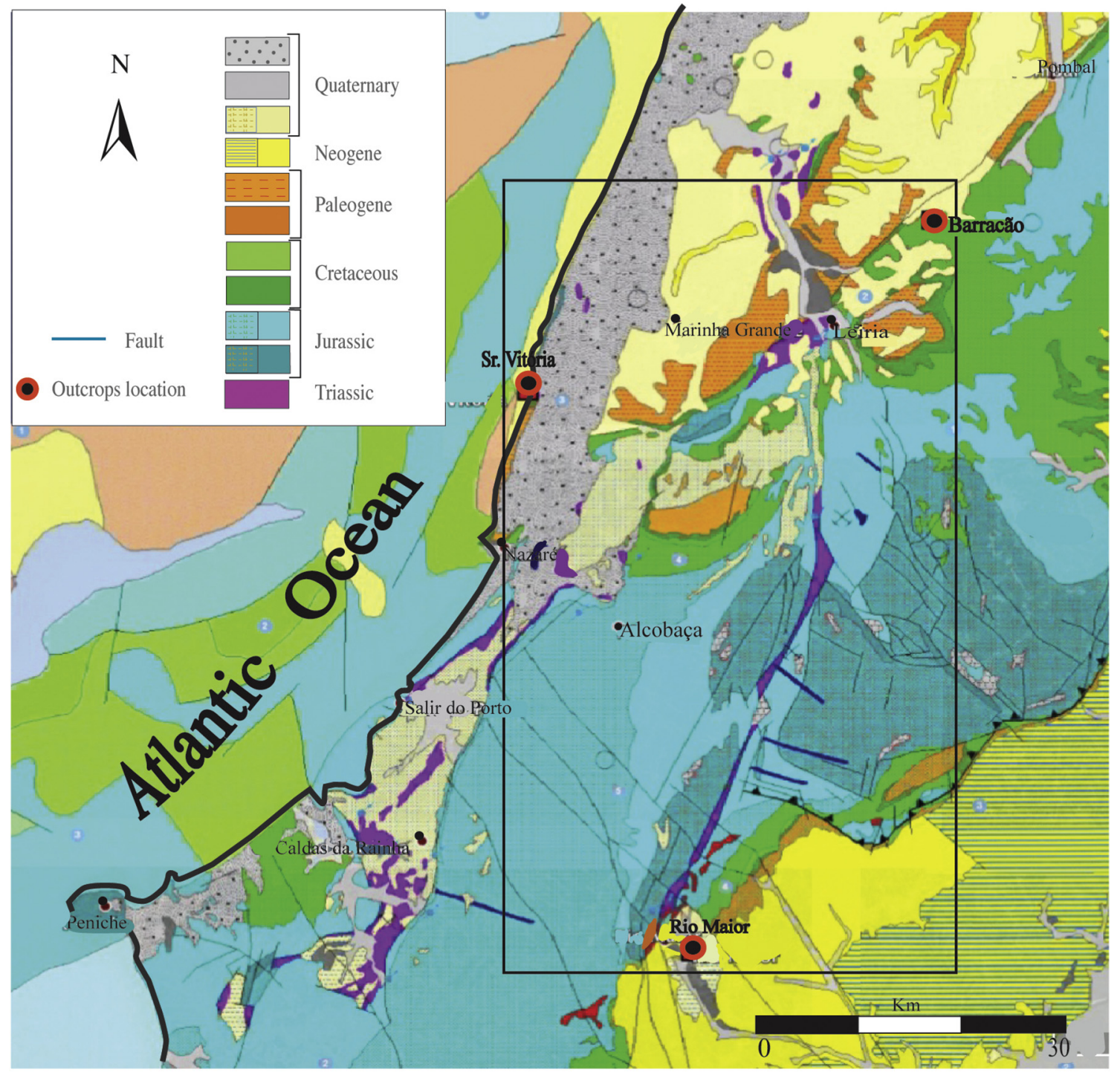

Fig. 2. Geology of western-central Portugal, with location of the sampled sites (adapted from the Geological map of Portugal, 1:500000, LNEG).

cover unit of Holocene aeolian sands (Fig. 5).

Here unit UBS13 is $\sim 27 \mathrm{~m}$ thick. The presence of fine yellow sands, laminated and rich in muscovite at the base, followed by thin beds of coarse sands with some mica reflects a littoral environment (Carnide Formation; Fig. 5); the upper part of the UBS13 unit consists of thick layers of white sands intercalated with thin beds of reddish silt (Roussa Formation; Fig. 5; Fig. 6 C, D). Two sediment samples were collected for ESR dating, from the base (PVIT1) and near the top (PVIT2) of UBS13.

\subsubsection{The Azinheira (Rio Maior) site}

At Rio Maior, the UBS13 unit is thick (up to $120 \mathrm{~m}$ ) and comprises (from the base to the top) kaolinitic fine white sands passing into medium sands and lignites intercalated with diatomites; its uppermost part is composed of sandy clay deposits with some gravelly layers (Zbyszewski, 1943, 1967; Pais et al., 2010).

A sandpit located $\left(39^{\circ} 19^{\prime} \mathrm{N} ; 8^{\circ} 55^{\prime} \mathrm{W}\right)$ near the village of Azinheira (ESE of Rio Maior; Fig. 1) was sampled for ESR dating. Samples RMAI1 and RMAI2 were collected, respectively, at $18 \mathrm{~m}$ and $3 \mathrm{~m}$ below the surface (Fig. 5; Fig. 6 E, F). RMAI1 was sampled in white sands of the UBS13 unit. RMI2 was sampled in the deposits of a probable terrace.

\subsection{Electron spin resonance dating}

Electron spin resonance dating is a palaeodosimetric method, i.e. the sample is used as a dosimeter for dating, having recorded the total radiation dose received since the event of interest, namely the time of deposition of quartz grains within the sediment, through the quantification of electrons trapped in mineral defects in relation to the irradiation (Grün, 1994; Ikeya, 1993). Since the end of 1960s, this method has been used to date materials such as tooth enamel (Falguères et al., 2016), corals, molluscs and continental carbonates (Bahain et al., 1995, 2007), as well as quartz grains from ash and fluvial deposits, and some flints (Ikeya, 1993; Falguères and Bahain, 2002). The dating of quartz by ESR was proposed in the early 1970s (McMorris, 1971), based on the presence of diverse paramagnetic ESR centres in its structure, with the first sedimentary quartz dating undertaken by Yokoyama et al. (1985). In this case, the dated event is the last sunlight exposure of the quartz grains during its transportation by water or wind, before its deposition and geological burial. This light exposure leads indeed to the release of the trapped electrons, i.e. a signal zeroing named optical bleaching. ESR dating of quartz is considered one of the best methods able to producing numerical ages for older Quaternary formations.

The age calculation implies determination of two main parameters: the total dose $\left(\mathrm{D}_{\mathrm{T}}\right)$, also referred to as the paleodose or equivalent dose 


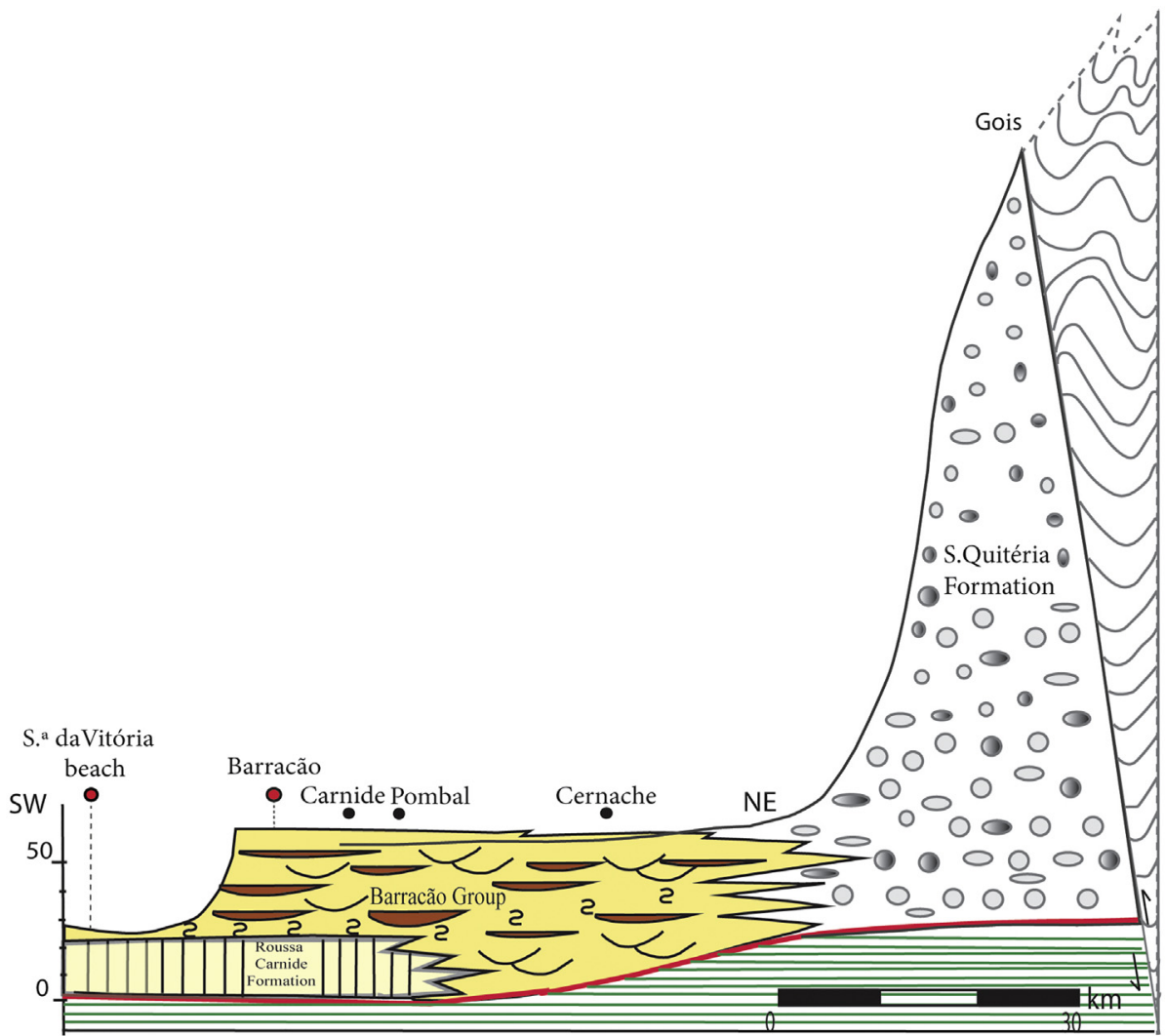

Fig. 3. Schematic geological cross section through the uppermost part of the Mondego Cenozoic Basin infill, showing the lithostratigraphic units that constitute UBS13. Legend: 1 - fluvial silts and clays; 2 marsh and swamp sediments (sands and silty clays); 3 - fluvial sands and gravels; 4 - marine and deltaic sands; 5 - alluvial-fan gravels and sands; 6 Mesozoic and Cenozoic; 7 - Variscan basement; 8 Lousã fault; 9 - sedimentary discordance (adapted from Cunha, 1992a).

(m)
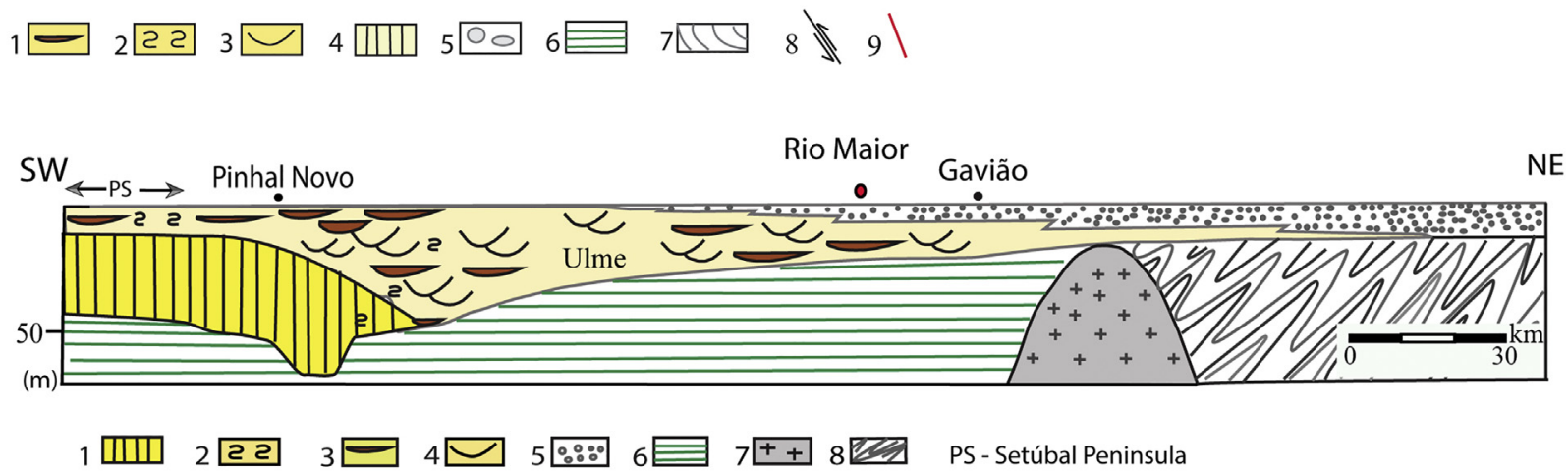

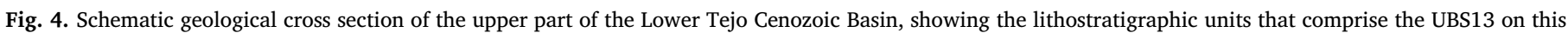

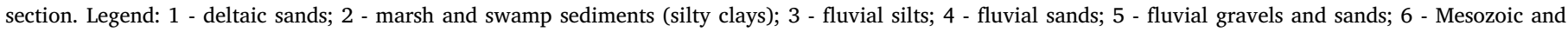
Cenozoic; 7 - granites; 8 - metamorphic rocks (adapted from Cunha, 1992a).

$\left(D_{e}\right)$, and the dose rate $\left(D_{a}\right)$, which is an estimation of the mean dose annually absorbed by the sample.

$\mathrm{D}_{\mathrm{e}}=\int{ }_{0}{ }^{\mathrm{T}} \mathrm{d}_{\mathrm{a}}(\mathrm{t}) \cdot \mathrm{dt}$

where $\mathrm{D}_{\mathrm{e}}$ is the equivalent dose of radiation received by the sample over time, $d_{a}$ is the annual dose rate of natural radiations and $t$ the age of the sample.

The equivalent dose is proportional to the concentration of trapped electrons in the sample and so to the ESR signal intensity. It is determined by a multi-aliquots additive method. The sample is divided into 10 or 15 aliquots artificially irradiated to different doses allowing the building of ESR intensity vs added doses growth curve. $D_{e}$ is determined by extrapolation of this growth curve to zero intensity using mathematical function.

In quartz, three paramagnetic centres are frequently used: the Germanium centre (Ge), the Aluminium centre (Al) and the Titanium centres (Ti). Each centre has different characteristics (e.g. differences in optical bleaching kinetics and/or radiation sensivity), so it is useful to combine studies of more than one centre in the same investigation (e.g. $\mathrm{Al}-\mathrm{Ti}$ centres are usually present in most of the quartz grains, allowing a multi-centres approach) to evaluate the reliability of the obtained $\mathrm{D}_{\mathrm{e}}$ (Toyoda et al., 2000; Rink et al., 2007; Tissoux et al., 2007; Duval and Guilarte, 2015).

Exposure of the quartz grains to sunlight leads to a release of trapped electrons (known as optical bleaching) but it should be notice that $\mathrm{Al}$ centre is not fully bleached during such exposure and thus a 'residual' ESR signal exists at the time of deposition of the quartz grains after their transportation. It is therefore necessary to determine this residual signal intensity that should be substracted to the intensities of natural and irradiated aliquots before the total dose fitting, in order to determine the dose accumulated after the deposition of the unit under consideration. According to Voinchet et al. (2015) the bleaching quality of quartz is dependent of the selection of grain-size fractions and the identification of transportation modes, especially in relation to the $\mathrm{Al}$ centre.

ESR is a dating method that has a large time-range potential, $\sim 30 \mathrm{ka}$ 


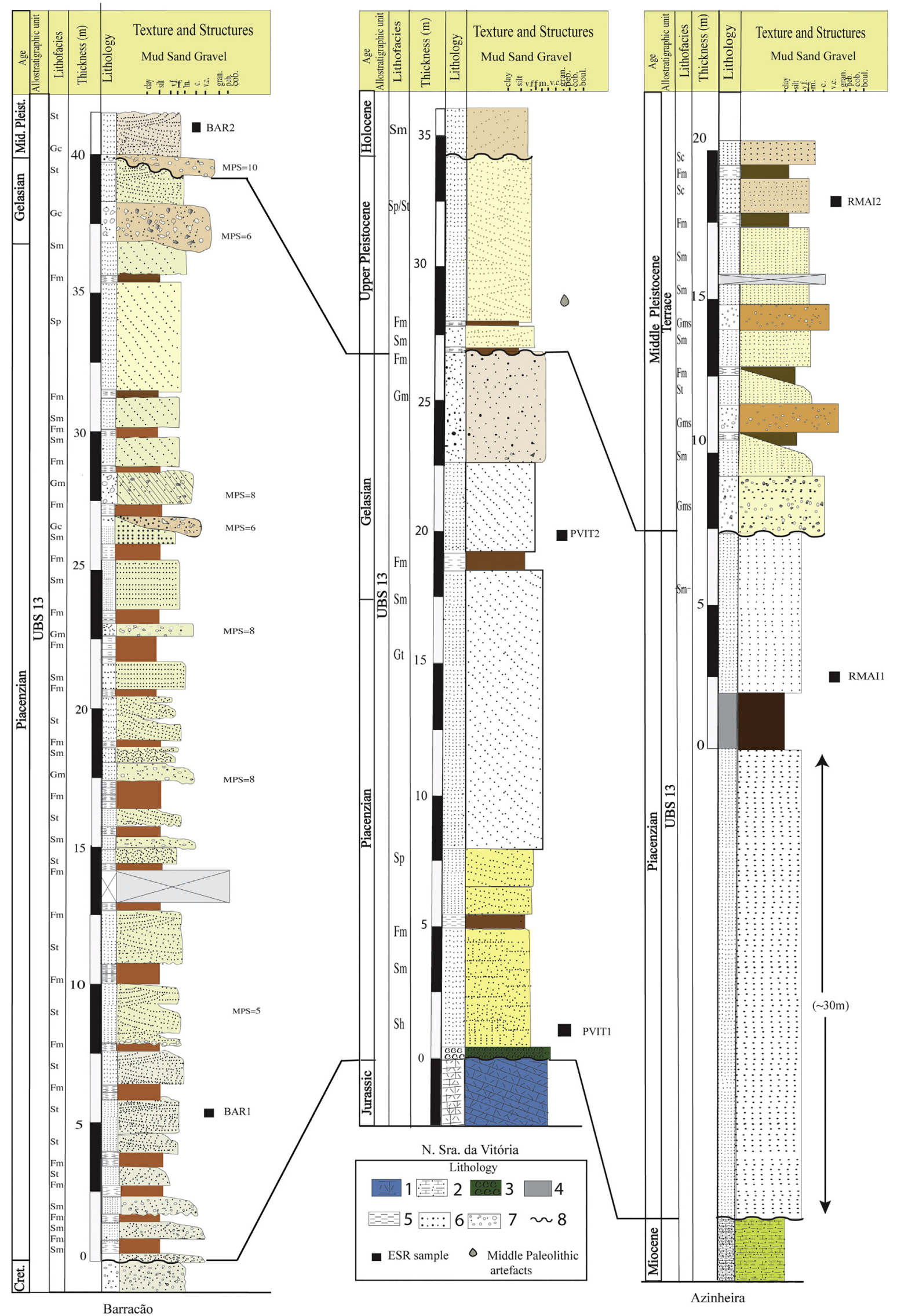

Fig. 5. Stratigraphic logs of the studied sites (Barracão, N. Sra. da Victória and Azinheira). The locations of the samples collected for ESR dating are indicated (black squares). Legend: 1 - limestones; 2 - marls; 3 - bioclastic levels interbedded with fine and medium sands (littoral); 4 - clays; 5 - silts; 6 - sands; 7 - gravels; 8 sedimentary discontinuity. Layers colours according to Munsell Soil classification. 

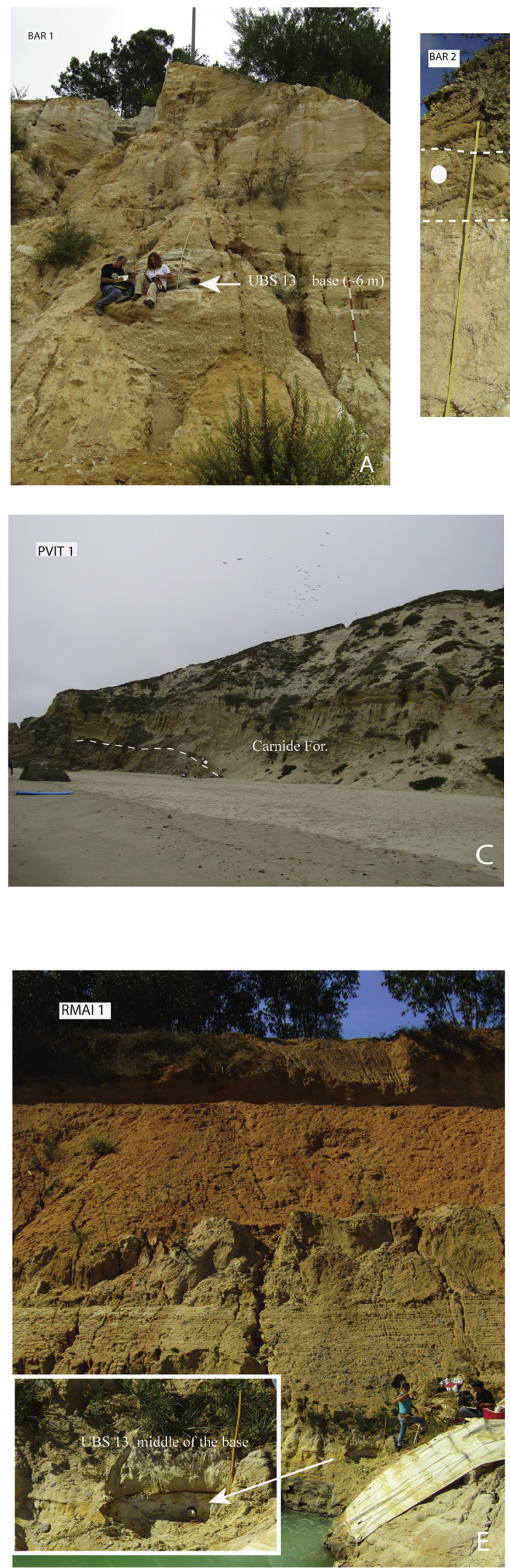

Fig. 6. Sections from which the six sediment samples for ESR dating were collected, respectively, at Barracão (A, B), N. Sra. da Vitória (C, D) and near Azinheira (Rio
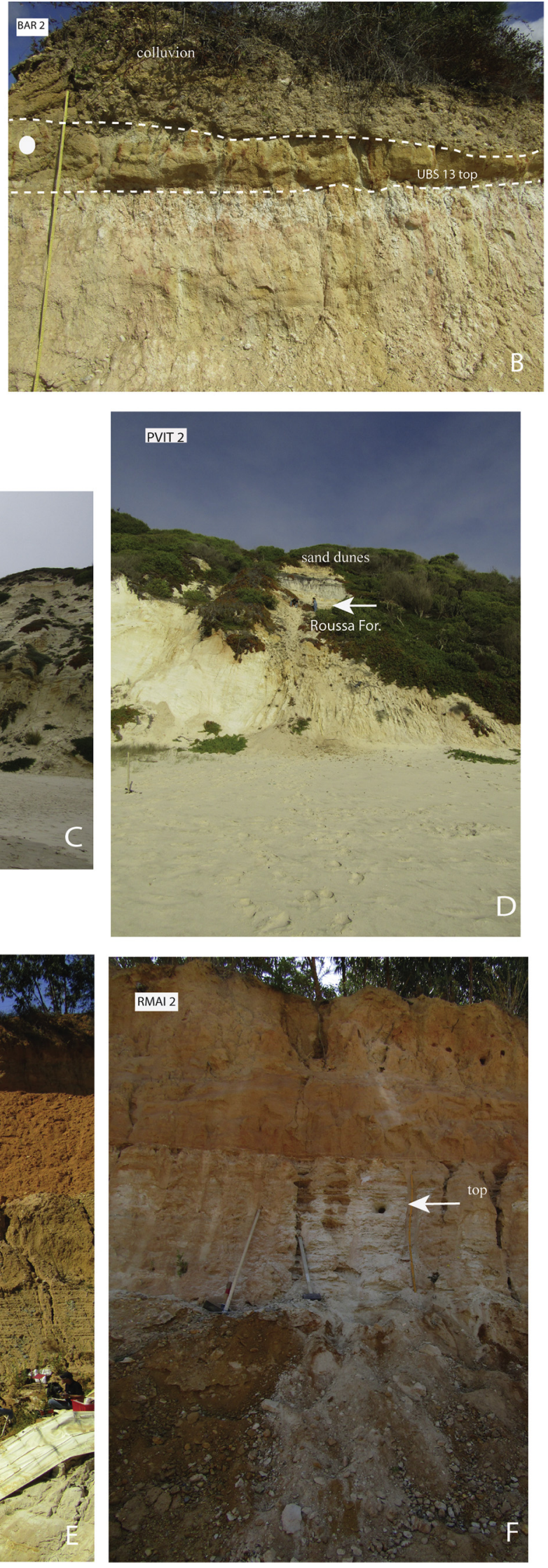

PVIT 2

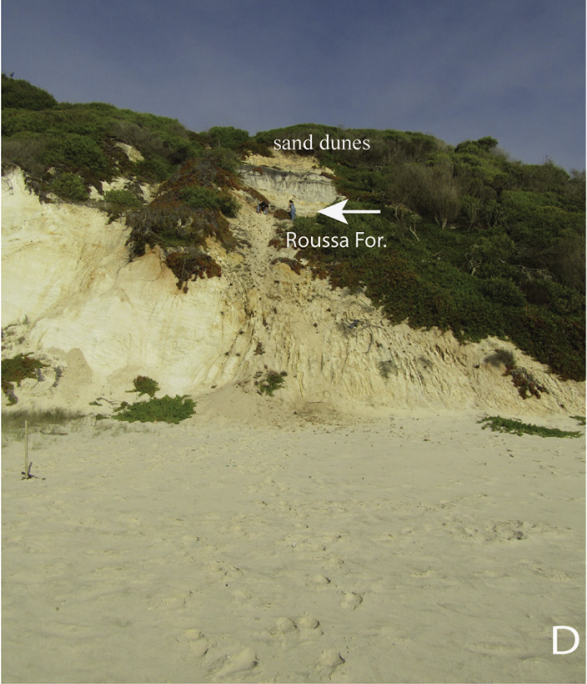

t

\footnotetext{
Maior; E, F).
} 
to 2-5 Ma (Voinchet et al., 2010). The ESR signal correlated with the $\mathrm{Al}$ centre usually has a high radiation-saturation level and thermal stability (e.g. Toyoda and Ikeya, 1991; Duval and Guilarte, 2015) so it could be used to date Lower Pleistocene (e.g. Rink et al., 2007; Duval et al., 2015) or even older materials (Laurent et al., 1998). In this context, ESR dating of optically bleached quartz has the potential to yield reliable numerical ages for the UBS13 sedimentary unit.

\subsubsection{Sediment samples}

Six sediment samples were collected for ESR dating during 2016 and 2017, at approximately the base and top of the UBS13 unit, at the Barracão, N. Sra. da Vitória and Azinheira sites (Fig. 1).

After a carefully cleaning of each section, a sediment sample of around $1 \mathrm{~kg}$ was collected in an opaque and watertight tube to prevent light exposure and loss of sediment. Systematic in situ gamma-ray measurements were performed for each sediment sample, using a portable gamma spectrometer (Canberra Inspector 1000 coupled with a 1.5*1.5 in. NaL(Tl) probe to evaluate the $\gamma$ dose rate (Mercier and Falguères, 2007), calculated according Guérin et al. (2011). For external dose rate (D) analyses and evaluation of water content, around $1 \mathrm{~kg}$ of sediment was collected from the ESR sampling point and bagged for high resolution low background gamma-ray spectrometry in the Laboratory of the Muséum National d'Histoire Naturelle (MNHN, Paris, France) and in the Laboratory of Natural Radioactivity of the University of Coimbra.

\subsubsection{Sample preparation}

Sample preparation for ESR analyses was carried out in darkroom conditions at the Department of Earth Sciences of the University of Coimbra, following the protocol established by Voinchet et al. (2003). Samples were wet-sieved to separate the $180-250 \mu \mathrm{m}$ grain-size fraction and rinsed using $\mathrm{HCl}(10 \%)$ and $\mathrm{H}_{2} \mathrm{O}_{2}(10 \%)$ to remove carbonates and organic matter, respectively. Heavy minerals and the K-feldspar fraction were removed using a heavy liquid solution of sodium polytungstate $\left(r=2.72 \mathrm{~g} / \mathrm{cm}^{3}\right.$ and $r=2.58 \mathrm{~g} / \mathrm{cm}^{3}$, respectively). Then magnetic minerals were eliminated using a powerful magnet. The quartz fraction was treated with $40 \% \mathrm{HF}$ and with $\mathrm{HCl}(10 \%)$ to remove the remaining feldspars and any remaining fluorides (details in Supplementary material (SM)). Each quartz sample was divided into 12 aliquots.

\subsubsection{ESR measurements}

The Multiple Aliquots Additive (MAA) dose approach for dating quartz grains was applied. Ten of these aliquots were irradiated with a calibrated ${ }^{137} \mathrm{Cs}$ Gammacell-1000 gamma source (dose rate $=200 \mathrm{~Gy}$ / h) at different doses ranging from 150 to $20,000 \mathrm{~Gy}$, carried out at CENIEH (Burgos, Spain). Each series of 12 aliquots was measured (ESR low-temperature; 107-109 K) using a Bruker EMX spectrometer at MNHN. One aliquot was kept as a natural reference and one aliquot was illuminated for $1000 \mathrm{~h}$ in a Dr. Honhle SOL2 solar simulator to determine the unbleachable part of the ESR-Al signal (Voinchet et al., 2003).

The intensity of Al signal was evaluated from peak-to-peak amplitude measurements between the top of the first peak $(\mathrm{g}=2.0185)$ to the bottom of the 16 th peak $(\mathrm{g}=2.002)$ of its hyperfine structure (Toyoda and Falguères, 2003). Details of the experimental conditions employed for the $\mathrm{Al}$ and $\mathrm{Ti}$ centres are provided in the Supplementary material. The angular dependence of the ESR signal was taken into account, measuring each aliquot three times after a $120^{\circ}$ rotation in the cavity. This protocol was repeated 2 to 4 times over distinct days to check the reproducibility of the $\mathrm{Al}$ signal. For this center, residual signal intensity remaining after optical bleaching was substracted to the intensities of all the other aliquots before fitting.

The ESR intensity for the $\mathrm{Ti}-\mathrm{Li}$ centre was measured from peak to baseline amplitude around $g=1.913-1.915$ (option D), following Duval and Guilarte (2015), with an excellent dose response to irradiation. The Ti centre showed a complete resetting of the ESR signal after the artificial bleaching.

A mean ESR intensity value and a standard deviation were derived from all the measurements, and used to evaluate the precision of the ESR data obtained from each centre (available in Supplementary material).

For $\mathrm{Al}$ centre, the equivalent dose (De) was determined using an exponential fitting function combining a saturating exponential function and a linear term (exp + lin function) (Duval, 2012; Voinchet et al., 2013). For the Ti-Li centre, the equivalent dose (De) was determined using a single saturating exponential function (SSE) (for details see Voinchet et al., 2013). These fitting were performed using the Microcal Origin Pro 8 SR5 software, with data weighting by the inverse of the squared intensities, $1 / \mathrm{I}^{2}$ (cf. Yokoyama et al., 1985) (in Supplementary material).

\subsubsection{Dose-rate evaluation and age calculation}

Radioelements contents ( $\mathrm{U}$, Th and daughters, and $\mathrm{K}$ ) were determined by high-resolution low-background gamma-ray spectrometry to derive external alpha and beta dose-rate components using the doserate conversion factors from Guérin et al. (2011).

The dose rate $D$ is expressed as $D=D_{\text {int }}+D_{\text {ext }}+D_{\text {cosmic. }}$.

where D, $D_{\text {int }}, D_{\text {ext }}$ and $D_{\text {cosmic }}$ are the total, internal, external and cosmic dose-rate components, respectively (Duval et al., 2017).

The grain thickness removed after HF etching was assumed to be $20 \mu \mathrm{m}$, so that the external alpha contribution was considered to be negligible, because these particles only penetrate about $25 \mu \mathrm{m}$ in the mineral. Values were corrected for $\alpha$ and $\beta$ attenuation of spherical grains (Brennan et al., 1991; Brennan, 2003). Water content was determined by measuring the difference in mass between the natural sample and the same sample dried for one week in an oven with the water attenuation correction based on Grün (1994). Cosmic dose rate was determined according to Prescott and Hutton (1994), based on the altitude, latitude and longitude of each section.

In the age calculation, the annual dose rate (Da) was calculated from the radionuclide activity in the sediments, taking into account both in situ and laboratory gamma-ray spectrometry measurements (see Table S5).

\subsection{Laboratory characterization of texture and mineral composition of the samples}

\subsubsection{Grain-size analysis}

Grain-size analyses of sediment samples were carried out by integration of the following: (i) for the fraction $>63 \mu \mathrm{m}$, sieving with a sieve tower with $1 / 2 \Phi$ increments, and (ii), for the fraction $<63 \mu \mathrm{m}$, by using a Beckman Coulter LS230 laser granulometer (measurement range of 0.04 to $2000 \mu \mathrm{m}$ ). Visual inspection of grain-size distribution curves allowed the identification and interpretation of unimodal or multimodal subpopulations.

\subsubsection{Mineral composition}

Analyses of sediment composition were based on binocular microscope observation and X-ray powder diffraction (Department of Earth Sciences, University of Coimbra) using a Philips PW 3710 X-ray diffractometer with a $\mathrm{Cu}$ tube, at $40 \mathrm{kV}$ and $20 \mathrm{nA}$. The mineralogical composition of the $<2 \mu \mathrm{m}$ fraction was obtained in oriented samples before and after ethylene glycol treatment and heating up to $550^{\circ} \mathrm{C}$. The percentages of clay minerals in each sample were determined through the peak areas of mineral presence, with the use of specific correction parameters. 
Table 2

Clay mineralogy and clay percentages of the samples collected at the Barracão, N. Sra. da Vitória and Azinheira sites.

\begin{tabular}{llll}
\hline Laboratory code & Illite (\%) & Kaolinite (\%) & Smectite (\%) \\
\hline BAR1 & 30 & 70 & 0 \\
BAR2 & 13 & 87 & 0 \\
PVIT1 & 37 & 8 & 54 \\
PVIT2 & 30 & 70 & 0 \\
RMAI1 & 9 & 91 & 0 \\
RMAI2 & 19 & 71 & 0 \\
\hline
\end{tabular}

\section{Results}

\subsection{Texture and mineral composition of the samples}

From the Barracão site, the samples BAR1 and BAR2 have light grey (10 YR 8/1) and light yellow (10YR 8/3) colours, respectively. The mean grain size of BAR1, which is dominated by medium coarse sand, is $0.39 \mathrm{~mm}$. The average grain-size fractions and parameters (Table 1) consist of $84 \%$ sand, $5 \%$ silt and $1 \%$ clay, very fine skewed (1.36), leptokurtic (6.01) and poorly sorted (1.88). BAR2 is a medium to coarse sand, with average grain-size components of $72 \%$ sand, $13 \%$ silt and $6 \%$ of clay. The mean grain size is $\sim 0.28 \mathrm{~mm}$, very poorly sorted (3.04) and mesokurtic (3.66) with a very fine-skewed (1.36) distribution. The claymineral composition of this sample (Table 2) is dominated by kaolinite, followed by illite, although the sample collected at the base of the UBS13 (BAR1) has a higher illite percentage (30\%) than that (BAR2) from the top (11\%). The sand fraction is composed of quartz, quartzite and feldspars.

From the N. Sra. Vitória site, samples PVIT1 and PVIT2 have a light grey (10 YR 8/3) and light yellow (10 YR 8/2) colour, respectively. PVIT1 is fine sand composed of quartz and phylosilicates (mainly muscovite), with a mean grain size of $\sim 0.13 \mathrm{~mm}$. The average grainsize fractions are $82 \%$ sand, $15 \%$ silt and $1 \%$ clay (Table 1 ); it is moderately well sorted (1.46), very fine skewed (1.88) and very leptokurtic (7.55). The clay fraction is composed of smectite (54\%), illite (37\%) and kaolinite (8\%). PVIT2 consists of medium sand, comprising quartz (50\%), feldspar (30\%), phyllosilicates (15\%) and oxides $(5 \%)$, with average grain-size components of $93 \%$ sand, $5 \%$ silt and $2 \%$ clay. The mean grain size is $\sim 0.31 \mathrm{~mm}$, poorly sorted (1.51) with very fine skewed (3.33) distribution and very leptokurtic (15.04). Clay minerals present (Table 2 ) are kaolinite $(70 \%)$ and illite $(30 \%)$.

Regarding the samples from Azinheira (RMAI1 and RMAI2), they are light grey (10YR 8/2), consisting of fine and medium sands (mean grain size $\sim 0.17$ and $0.28 \mathrm{~mm}$, respectively), both being poorly sorted $(1.44 ; 1.95)$, very leptokurtic (12.59) and leptokurtic (5.66), very fine skewed (2.98) in the case of RMAI1 and fine skewed (1.11) for RMAI2 (Table 1). On average, the sediment comprises $92 \%$ sand, $6 \%$ silt and $2 \%$ clay (RMAI 1 ) and $74 \%$ sand, $14 \%$ silt and $6 \%$ clay (RMAI2). The sand fraction minerals are quartz and feldspars, with some phyllosilicates (e.g. muscovite) and iron oxides. The clay fractions (Table 2) in RMAI1 and RMAI2 (respectively), comprise kaolinite (91/71\%) followed by illite (9/19\%).

\subsection{ESR dating of optically bleached quartz grains}

The ESR analytical data are listed in Tables 3 and 4. The Ti - Li centre signal intensities of quartz grains were determined only for top layers.

The final $D_{e}$ values for each sample were calculated from the average ESR intensity values, with the errors for each point corresponding to the nine measures. The relative bleaching component values (Table 3) vary within a narrow range (around $60 \pm 5 \%$ ), suggesting similar bleaching conditions for all samples, which is a finding consistent with previous observations (Voinchet et al., 2007; del Val, 
Table 3

- Sample information, external $\beta$ dose rate, dose rate in situ, cosmic dose and bleaching.

\begin{tabular}{|c|c|c|c|c|c|}
\hline UBS 13 & Laboratory code & External $\beta$ dose rate $(\mathrm{Gy} / \mathrm{Ka})$ & $\mathrm{D} \gamma$ in situ $(\mathrm{Gy} / \mathrm{Ka})$ & Cosmic dose rate $(\mathrm{Gy} / \mathrm{Ka})$ & $\mathrm{Bl}(\%)$ \\
\hline Barracão - base & BAR1 & $0.344 \pm 12$ & $0.339 \pm 20$ & $0.021 \pm 0.001$ & $54 \pm 1.5$ \\
\hline Barracão - top & BAR2 & $0.426 \pm 12$ & $0.516 \pm 26$ & $0.155 \pm 0.008$ & $60 \pm 2.7$ \\
\hline N. Sra. da Vitória - base & PVIT1 & $2.565 \pm 21$ & $1.137 \pm 57$ & $0.023 \pm 0.001$ & $50 \pm 0.5$ \\
\hline N. Sra. da Vitória - top & PVIT2 & $0.460 \pm 11$ & $0.241 \pm 12$ & $0.068 \pm 0.003$ & $62 \pm 2$ \\
\hline Azinheira - base & RMAI1 & $0.576 \pm 14$ & $0.332 \pm 17$ & $0.0025 \pm 0.001$ & $62 \pm 1.4$ \\
\hline Azinheira - top & RMAI2 & $1.114 \pm 17$ & $1.267 \pm 63$ & $0.109 \pm 0.005$ & $60 \pm 2$ \\
\hline
\end{tabular}

2019). The quality of fit is good overall for these samples, with ajusted $r^{2}$ values of $>0.98$

According to Duval (2012), the reliability of the fitting results obtained from the Al centre should be questioned if the relative errors for the fitted parameters are $>25 \%$. All studied samples have relative $D_{e}$ errors $<14 \%$.

For the Ti centre, the $\mathrm{D}_{\mathrm{e}}$ obtained in this study had a high quality of the fit, with adjusted $r^{2}$ values $>0.99$ and relative errors $<50 \%$, as described by Duval and Guilarte (2015), with the exception of PVIT2 (Table 4). In the studied samples younger ages were obtained using the Ti centre than using the Al centre, except for BAR2. The $\mathrm{D}_{\mathrm{e}}$ obtained for samples from Azinheira (RMAI2) and N. Sra. da Vitória (PVIT2) was similar (Table 4).

Radionuclide activity values (with $\gamma$ dose measured in situ and in the laboratory) provide consistent results at $1 \sigma$ (Table S5).

The ESR Al age obtained for the base of UBS13 at the Barracão site (BAR1) is $2188 \pm 73 \mathrm{ka}$. The age estimates for the BAR2 sample are $417 \pm 35 \mathrm{ka}$ and $517 \pm 19 \mathrm{ka}$, for the $\mathrm{Al}$ and $\mathrm{Ti}-\mathrm{Li}$ centres, respectively. As described above, the Ti - Li signal saturates with lower doses (see Fig. 7.IV) than the Al signal. For Bar 2, only 8 aliquots could be well fitted with the ESR Al center.

From the N. Sra. da Vitória site, the ESR age of the lower sample (PVIT1) collected at the base of the Carnide Formation provided an ESR Al age of $632 \pm 241 \mathrm{ka}$, which greatly underestimates the probable burial age. This sample has a much higher dose rate (Table 4) and $D_{e}$ than the sample collected at the top (PVIT2) and the fitted curve of the ESR signal intensity showed the behaviour described by Voinchet et al. (2013) for old sediment samples.

The ESR age of the PVIT2 sample, collected near the top of UBS13, is $1988 \pm 121 \mathrm{ka}$ based on the $\mathrm{Al}$ centre and $1599 \pm 60 \mathrm{ka}$ based on $\mathrm{Ti}$ - Li centre (Table 4).

The lower sample collected at Rio Maior (RMAI1) gave an ESR age of $2894 \pm 314 \mathrm{ka}$, based on the $\mathrm{Al}$ centre.

The sample RMAI2, collected from the deposits of a terrace, has a $D_{e}$ of $1839 \pm 174 \mathrm{~Gy}$; from the $\mathrm{Al}$ centre it had a well-fitted and defined curve (SSE fitting curve) and a total annual dose of $2515 \pm 71 \mu \mathrm{Gy} / \mathrm{yr}$, which resulted in a final ESR age of $731 \pm 69 \mathrm{ka}$. From the Ti $-\mathrm{Li}$ centre, the ERS age obtained was about 33\% lower (Table 4).

\section{Discussion}

It is interesting to see large differences in values of the environment annual dose from the top and the base of the same outcrops of the UBS13 unit; this can be explained in the main by different sediment sources and depositional conditions.

The De values derived from Al (EXPLIN) and Ti option D (SSE and EXPLIN) are mostly $1 \sigma$ consistent.

As in other studies, the ESR signal from the $\mathrm{Al}$ centre shows no saturation effects at high irradiation doses (e.g. Duval and Guilarte, 2015). In PVIT2, the Ti - Li signal could be used to determine whether the sediment has been well bleached at the time of deposition. The "radiation bleaching" phenomenon is observed in the ESR signal from the $\mathrm{Ti}-\mathrm{Li}$ centre at high irradiation doses (e.g. Fig. 7 IV) and the relative error is $>50 \%$ for the higher doses ( $>8000 \mathrm{~Gy}$ ) in most irradiated aliquots (Table S4, SM). The differences between the values resulting from the $\mathrm{Al}$ and $\mathrm{Ti}$ centres, suggest that bleaching in the $\mathrm{Al}$ centre at the time of deposition was satisfactory for all the samples, with the exception of sample BAR2 (Table 3). In this sample, the De calculated from the $\mathrm{Al}$ centre is lower than from the $\mathrm{Ti}$ - Li centre, but the chronologies provided by each centre are scattered (Table 4). This may be due to different thermal stabilities of the $\mathrm{Al}$ and $\mathrm{Ti}-\mathrm{Li}$ centres (Toyoda and Ikea, 1994).

It was expected that the ESR age of PVIT1 would be similar to the biostratigraphic age of the Vale Farpado site $(\sim 3.7 \mathrm{Ma})$. PVIT1 has a value of external $\beta$ dose much higher (Table 3 ) than all the others; this is linked to the large amount of K-feldspar and muscovite present in the sample. This sample has no desequilibrium in the radioactive chain that could explain an increase of dose rate with burial time. PVIT1 was collected close to a major fault (there is evidence of post-depositional faulting and the limestone bedrock is strongly fractured (Cabral et al.,

Table 4

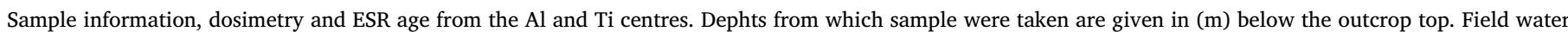
content (WC) was calculated as mass water/mass* $100 \%$.

\begin{tabular}{|c|c|c|c|c|c|c|}
\hline UBS13 unit & Barracão base & Barracão top & N. Sra. Vitória beach base & N. Sra. Vitória beach top & Azinheira - base & Azinheira - top \\
\hline Laboratory code & BAR1 & BAR2 & PVIT1 & PVIT2 & RMAI1 & RMAI2 \\
\hline Depht (m) & 36 & 1.5 & 21 & 8 & 17 & 3.6 \\
\hline Elevation (m) & 160 & 190 & 4.5 & 21 & 73 & 87.5 \\
\hline Grain-size $(\mu \mathrm{m})$ & $250-180$ & $250-180$ & $250-180$ & $250-180$ & $250-180$ & $250-180$ \\
\hline W. C. (\%) & 12 & 21 & 25 & 18 & 22 & 22 \\
\hline${ }^{238} \mathrm{U}(\mathrm{ppm})$ & $2.10 \pm 0.07$ & $1.95 \pm 0.07$ & $1.54 \pm 0.087$ & $0.61 \pm 0.06$ & $0.93 \pm 0.065$ & $3.97 \pm 0.096$ \\
\hline${ }^{232}$ Th (ppm) & $3.78 \pm 0.09$ & $8.13 \pm 0.11$ & $6.66 \pm 0.14$ & $1.14 \pm 0.08$ & $2.21 \pm 0.09$ & $17.32 \pm 0.16$ \\
\hline${ }^{40} \mathrm{~K}(\%)$ & $0.10 \pm 0.01$ & $0.20 \pm 0.006$ & $4.82 \pm 0.02$ & $0.87 \pm 0.02$ & $0.84 \pm 0.01$ & $0.96 \pm 0.02$ \\
\hline Da (total) $\left(\mu \mathrm{Gy} \cdot \mathrm{a}^{-1}\right)$ & $713 \pm 26$ & $1110 \pm 31$ & $3734 \pm 63$ & $772 \pm 18$ & $938 \pm 24$ & $2515 \pm 71$ \\
\hline De Al centre (Gy) & $1561 \pm 49$ & $458 \pm 35$ & $2360 \pm 900$ & $1534 \pm 92$ & $2713 \pm 293$ & $1839 \pm 174$ \\
\hline Adj. square & 0.99 & 0.99 & 0.94 & 0.98 & 0.98 & 0.98 \\
\hline $\mathrm{Al}$ age (ka) & $2188 \pm 73$ & $417 \pm 35$ & $632 \pm 241$ & $1988 \pm 121$ & $2894 \pm 314$ & $731 \pm 69$ \\
\hline De Ti centre (Gy) & - & $574 \pm 20$ & - & $1232 \pm 45$ & - & $1233 \pm 60$ \\
\hline Adj. square & - & 0.99 & - & 0.988 & - & 0.998 \\
\hline $\mathrm{Ti}$ - Li centre Ti age (ka) & - & $517 \pm 19$ & - & $1599 \pm 60$ & - & $490 \pm 24$ \\
\hline
\end{tabular}



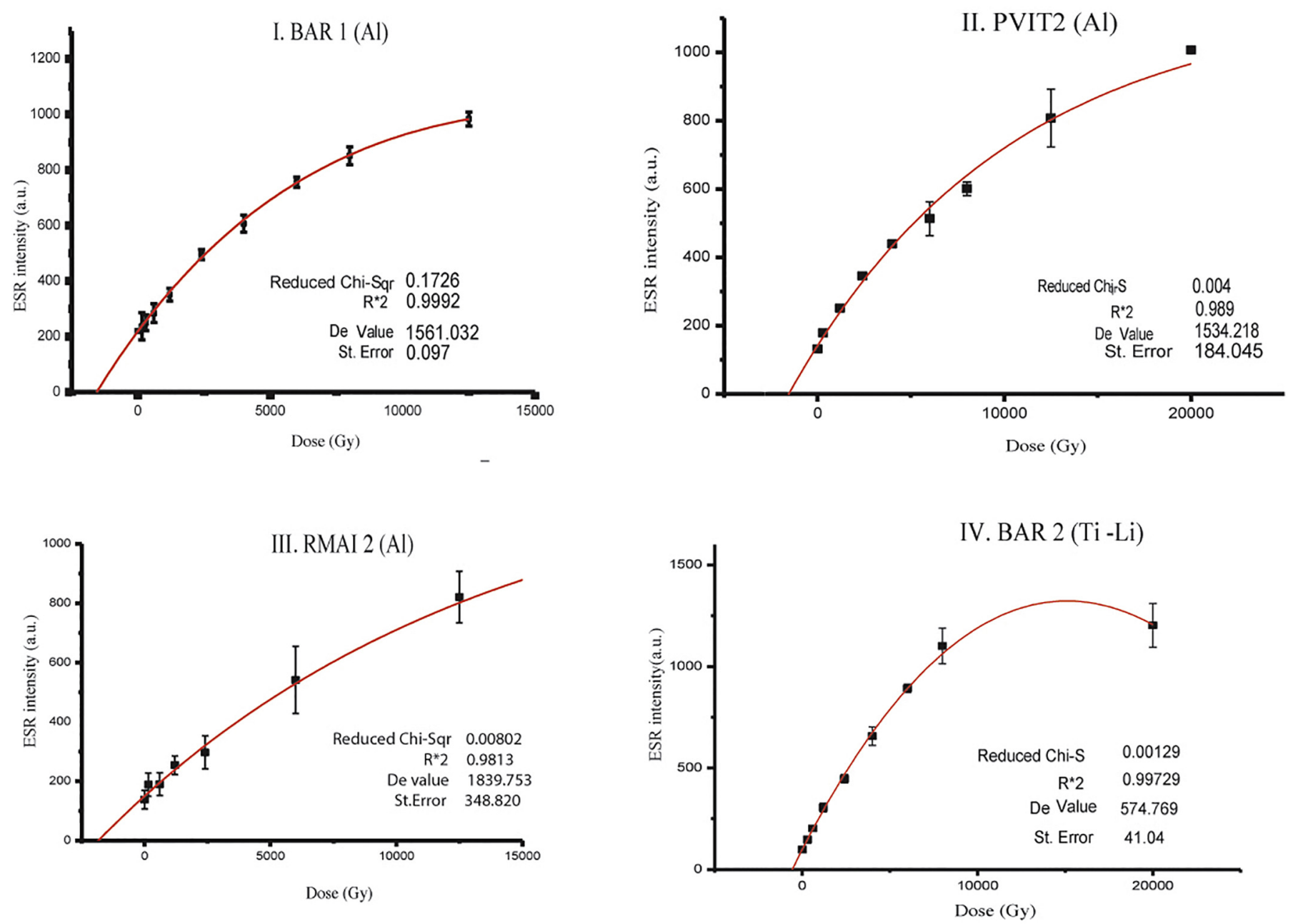

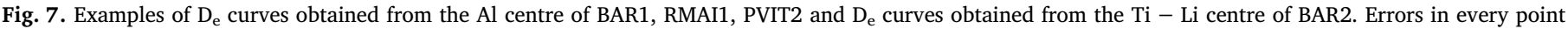
correspond to the 3 measures standard deviation (see Table S3).

2018) providing the possibility of a different time-temperature history, so that the obtained ESR age could correspond to the probable age of the most recent fault activity (caused by quartz in fault gouges being exposed to shearing).

For the RMAI1 and BAR1 samples, which are from locations significantly inland $(\sim 20 \mathrm{~km}$, Fig. 1$)$, their expected burial age is $\sim 3.0-2.5 \mathrm{Ma}$. The ESR age estimates (Al centre) calculated for the UBS13 basal and middle stratigraphic deposits are $2894 \pm 314$ ka for RMAI1 and $2188 \pm 73 \mathrm{ka}$ for BAR1. Thus, it seems that the ESR ages obtained are within the expected period of time (allowing for the error range).

Unfortunately, there are still no other absolute ages in Portugal for the uppermost deposits of the UBS13 unit. Regarding the expected age for these deposits, $\sim 2.0-1.8 \mathrm{Ma}$, the ESR Al age obtained during the present work from the sample PVIT2 $(1988 \pm 121 \mathrm{ka})$ is as expected.

So, the estimated ESR ages determined from $\mathrm{Al}$ centres from UBS13 sediments range within the Piacenzian and Gelasian.

The ESR ages obtained for BAR2 and RMAI2 are too young to be UBS13 burial ages and the field data suggests that these samples were collected from fluvial terrace deposits (Fig. 5 and Fig. 6 B).

The present study confirms that the $\mathrm{Ti}-\mathrm{Li}$ centre ESR signal intensities of quartz grains is consistent and grew with the artificial doses for samples from the Middle Pleistocene (some beyond $8000 \mathrm{~Gy}$ ), but this seems to result in underestimated ESR ages for successions from the Pliocene and Lower Pleistocene (Tissoux et al., 2007). It also demonstrates that ESR ages are yielded with large error ranges for time older than 3.0-2.5 Ma if the De is not very high (up to 3000 Gy is required for increased age rehabilitee). The difficulties in obtaining reliable ESR age estimates for the studied Pliocene and Lower Pleistocene deposits result from low $\mathrm{D}_{\mathrm{e}}$ values $(<2700 \mathrm{~Gy}$ ) of these sediments, which has had a direct consequence on the age determination.

\section{Conclusions}

In this study, ESR dating has been used for the first time to date the allostratigraphic unit UBS13, which represents the culminant sedimentary infilling of the Lower Tejo and Mondego Cenozoic basins, with a depositional age between $\sim 3.7 \mathrm{Ma}$ (older basal deposits) and, probably, $\sim 1.8 \mathrm{Ma}$ (uppermost deposits).

It has been confirmed that the $\mathrm{Ti}-\mathrm{Li}$ centre provides unreliable ESR data (underestimated ages) for successions having Pliocene to Early Pleistocene burial ages.

The ESR ages (Al centre) obtained for the UBS13 basal and middle stratigraphic levels indicate a Piacenzian age, reaching $3 \mathrm{Ma}$. The ESR ages (Al centre) obtained for the uppermost UBS13 deposits indicate as very probable an age of $\sim 1.8 \mathrm{Ma}$. This study shows that the ESR method using the $\mathrm{Al}$ signal, in optically bleached quartz, is available for dating deposits as old as Piacenzian (Late Pliocene). This result is internationally important because it represents the first numerical ages obtained in western Iberia for the uppermost levels of the Cenozoic basins, which predate fluvial incision into the basin-fill sediments.

This research should be developed in the immediate future, by using 
ESR dating (Al centre) to date the uppermost stratigraphic levels in other sites of the Lower Tejo and Mondego Cenozoic basins, as well as in other Iberian Cenozoic basins. This dating is crucial to investigate the role played by tectonic activity, climate and eustasy in the transition from basin-fill to fluvial incision and to establish the precise timing of this transition.

\section{Funding}

This work was funded by Fundação para a Ciência e Tecnologia (FCT), through a PhD Scholarship (SFRH/BD/116038/2016) attributed to Maria Margarida Lopes Correia Gomes Porto Gouveia. This work was co-funded by Bolsa Pessoa and by FCT, with FEDER and COMPETE 2020 funds, through projects UID/MAR/04292/2019 — MARE (Marine and Environmental Sciences Centre) and UID/GEO/04683/2019 — ICT.

\section{Declaration of Competing Interest}

As one author, I declare for my honor that there is any conflict of interest in publication of this manuscript Gouveia et al., 2019, with the title:

Electron spin resonance dating of the culminant allostratigraphic unit of the Mondego and Lower Tejo Cenozoic basins (W Iberia), which predates fluvial incision into the basin-fill sediments.

\section{Acknowledgements}

Thanks to Ana Barbara Costa and Pu Yang for assistance during fieldwork and in the Sedimentology Laboratory. We thank Hugo Filipe Vilares for improvements in the use of English. The authors also thank the relevant contributions made by Prof. David Bridgland, as Managing Guest Editor, and by the reviewers.

\section{Appendix A. Supplementary data}

Supplementary data to this article can be found online at https:// doi.org/10.1016/j.gloplacha.2019.103081.

\section{References}

Azevêdo, M.T., 1982. As formações quaternárias continentais da Península de Setúbal e sua passagem às formações litorais. Cad Lab Xeol Laxe Geologia 3, 287-303.

Bahain, J.J., Yokoyama, Y., Falguères, C., Bibron, R., 1995. Datation par résonance de spin électronique (ESR) de carbonates marins quaternaires (Coraux et coquilles de mollusques) Electron spin resonance (ESR) dating of quaternary marine carbonates (corals and mollusc shells). Quaternaire 6 (1), 13-19.

Barbosa, B., 1983. Argilas Especiais do Barracão - Pombal. Est. Not. Trab. Serv. Fomento Mineiro 25 (3-4), 193-212.

Barbosa, B., 1995. Alostratigrafia e litostratigrafia das unidades continentais da Bacia Terciária do Baixo Tejo. Relações com o eustatismo e a tectónica. Univ. de Lisboa, pp. 253 (Ph.D. Thesis).

Benedetti, M.M., Haws, J.A., Funk, C.L., Daniels, J.M., Hesp, P.A., Bicho, N.F., Minckley, T.A., Ellwood, B.B., Forman, S.L., 2009. Late Pleistocene raised beaches of coastal Estremadura, Central Portugal. Quat. Sci. Rev. 28, 3428-3447.

Brennan, B.J., 2003. Beta doses to spherical grains. Radiat. Meas. 37 (4-5), 299-303.

Brennan, B.J., Lyons, R.G., Philips, S.W., 1991. Attenuation of alpha particle track dose for spherical grains. Int. J. Radiat. Appl. Instrum. Part D. Nucl. Tracks Radiat. Meas. 18, 249-253.

Cabral, J., Ribeiro, P., Ramos, A., Cunha, P.P., 2018. Diapiric activity affecting late Pliocene to Pleistocene sediments under a tectonic compressive regime: an example from the Western Iberian margin (Sra da Vitória beach, Central Portugal). J. Iber. Geol. 44 (3), 431-445.

Cachão, M., 1989. Contribuição para o estudo do Pliocénico Marinho Português (sector Pombal/Marinha Grande). Dissertação apresentada no âmbito das provas de Aptidão Pedagógica e Capacidade Científica. Fac. de Ciências, Universidade de Lisboa, pp. 204.

Cachão, M., 1990. Posicionamento biostratigráfico da jazida pliocénica de Carnide (Pombal). Gaia 2, 11-16.

Calvo, J., Daams, R., Morales, J., Lopez-Martínez, N., Agusti, J., Anadon, P., Armenteros, I., Cabrera, L., Civis, J., Corrochano, A., Diaz-Molina, M., Elizaga, E., Hoyos, M., Martin-Suarez, E., Martínez, J., Moissenet, E., Muñoz, A., Pérez-Garcia, A., PérezGonzalez, A., Portero, J., Robles, F., Santisteban, C., Torres, T., Van der Meulen, A.J.,
Vera, J., Mein, P., 1993. Up-to-date Spanish continental Neogene synthesis and paleoclimatic interpretation. Rev. Soc. Geol. Esp. 6 (3-4), 29-40.

Choffat, P., 1889. Observations sur le Pliocéne du Portugal. Mém. Soc. Belge Geol. Paleont. Hydrol. 3, 119-123.

Choffat, P., 1903. L'Ifralias et le Sinémurien au Portugal. Comun. Serv. Geol. 5, 4-114 Portugal, Lisboa.

Cunha, P.P., 1992a. Estratigrafia e sedimentologia dos depósitos do Cretácico Superior e Terciário de Portugal central, a Leste de Coimbra/Stratigraphy and sedimentology of the Upper Cretaceous and Tertiary of central Portugal, east of Coimbra. University of Coimbra, pp. 262 (Ph.D. Thesis).

Cunha, P.P., 1992b. Establishment of Unconformity-Bounded Sequences in the Cenozoic Record of the Western Iberian Margin and Synthesis of the Tectonic and Sedimentary Evolution in Central Portugal During Neogene. Abstracts of the First Congress R.C.A.N.S. - "Atlantic General Events During Neogene", Lisboa. pp. 33-35.

Cunha, P.P., 1996. Unidades litostratigráficas do Terciário da Beira-Baixa (Portugal). Com Inst. Geo Mineiro 82, 87-130.

Cunha, P.P., 2019. Cenozoic Basins of Western Iberia: Mondego, lower Tejo and Alvalade Basin. In: Quesada, C., Oliveira, J.T. (Eds.), The Geology of Iberia: A Geodynamic Approach. Regional Geology Reviews. Vol. 4. Springer International Publishing, pp. 105-130. https://doi.org/10.1007/978-3-030-11190-8. Cenozoic Basins, Chapter 4.

Cunha, P.P., Barbosa, B.P., Pena dos Reis, R., 1993. Synthesis of the Piacenzian onshore record, between the Aveiro and Setúbal parallels (Western Portuguese margin). Ciências da Terra 12, 35-43.

Cunha, P.P., Pais, L., Legoinha, P., 2009. Evolução geológica de Portugal continental durante o Cenozóico - sedimentação aluvial e marinha numa margem continental passiva (Ibéria ocidental). $6^{\circ}$ Simposio sobre el Margem Ibérico Atlántico MIA09. pp. 9-20.

Cunha, P.P., Almeida, N.A.C., Aubry, T., Martins, A.A., Murray, A.S., Buylaert, J.-P., Sohbati, R., Raposo, L., Rocha, L., 2012. Records of human occupation from Pleistocene river terrace and aeolian sediments in the Arneiro depression (lower Tejo River, central eastern Portugal). Geomorphology 165-166, 78-90. https://doi.org/ 10.1016/j.geomorph.2012.02.017.

Cunha, P.P., Martins, A.A., Gouveia, M.P., 2016. As escadarias de terraços de Rodão à Chamusca (Baixo Tejo) - caracterização e interpretação de dados sedimentares, tectónicos, climáticos e do paleolítico. Estudos do Quaternário 14, 1-24.

Cunha, P.P., de Vicente, G., Martín-González, F., 2019. Chapter 5 - Cenozoic sedimentation along the piedmonts of thrust related basement ranges and strike-slip deformation belts of the iberian variscan massif. In: Quesada, C., Oliveira, J.T. (Eds.), The Geology of Iberia: A Geodynamic Approach. Regional Geology Reviews. Vol. 4. Springer International Publishing, pp. 131-165. https://doi.org/10.1007/978-3-03011190-8. Cenozoic Basins.

de Vicente, G., Cloetingh, S., Van Wees, J.D., Cunha, P.P., 2011. Tectonic classification of Cenozoic Iberian foreland basins. Tectonophysics 502 (1-2), 38-61. https://doi.org/ 10.1016/j.tecto.2011.02.007.

de Vicente, G., Cunha, P.P., Muñoz-Martín, A., Cloetingh, S.A.P.L., Olaiz, A., Vegas, R., 2018. The Spanish-Portuguese Central System: an example of intense intraplate deformation and strain partitioning. Tectonics 37, 4444-4469. https://doi.org/10. 1029/2018TC005204.

del Val, M., Duval, M., Medialdea, M., Bateman, M.D., Moreno, D., Arriolabengoa, M. Aranburu, A., Iriarte, E., 2019. First chronostratigraphic framework of fluvial terrace systems in the eastern Cantabrian margin (Bay of Biscay, Spain). Quat. Geochronol. 49, 108-114.

Dinis, P.A., Oliveira, A., 2016. Provenance of Pliocene clay deposits from the Iberian Atlantic margin and compositional changes during recycling. Sediment. Geol. 336, 171-182.

Diniz, F., 1984. Apports de la palynology à la connaissance du Pliocène portugais. In: Rio Maior: Un Basin de Référence pour l' histoire de la Flore, de la Végétation et du Climat de la Façade Atlantique de l europe Meridionale. Université des Sciences et Techniques de Languedoc, Montpellier, pp. 230 (Ph.D. Thesis).

Diniz, F., 2003. Os depósitos detrítico-diatomíticos de Abum (Rio Maior). Novos aspectos paleoflorísticos e implicações paleoclimáticas. In: Ciências da Terra, $N^{\circ}$ Especial V, 7 , CDRom: A49-A52.

Diniz, F., Mörner, N.-A., 1995. The Reuverian/Pretiglian transition in Rio Maior. In: Portugal. XIV International Congress INQUA, Schriften der Alfred-Wegner-Stiftung 2/ 95, 64.

Diniz, F., Silva, C.M., Cachão, M., 2016. O Pliocénico de Pombal (Bacia do Mondego, Portugal oeste): biostratigrafia, paleoecologia e paleobiogeografia. Estudos do Quaternário 14, 41-59.

Dolfus, G.F., Cotter, J.C.B., 1909. Mollusques tertiaries du Portugal. Le Pliocène au nord du tage (Plaisancian). 1re partie. Pelecypoda. Mem. Com. Serv. Geol 40, 1-103 Portugal, Lisboa.

Dowsett, H., Barron, J., Poore, R., 1996. Middle Pliocene sea surface temperatures: a global reconstruction. Mar. Micropaleontol. 27 (1-4), 13-25.

Dowsett, H., Robinson, M., Haywood, A.M., Hill, D.J., Dolan, A.M., Stoll, D.K., Chan, W., Abe-Ouchi, A., Chandler, M.A., Rosenbloom, N.A., Otto-Bliesner, L., Bragg, F.J., Lunt, D.J., Foley, K.M., Riesselman, C., 2012. Assessing confidence in Pliocene Sea surface temperatures to evaluate predictive models. Nat. Clim. Chang. 2, 365-371.

Duval, M., 2012. Dose response curve of the ESR signal of Aluminium center in quartz grains extracted from sediment. Ancient TL 30 (2), 41-49.

Duval, M., Guilarte, V., 2015. ESR dosimetry of optically bleached quartz grains extracted from Plio-Quaternary sediment: evaluating some key aspects of the ESR signal associated to the Ti-center. Radiat. Meas. 78, 28-41.

Duval, M., Bahain, J.J., Falgueres, C., Garcia, J., Guilarte, V., Grün, R., Martínez, K. Moreno, D., Shao, Q., Voinchet, P., 2015. Revisiting the ESR chronology of the early Pleistocene hominin occupation at Vallparadís (Barcelona, Spain). Quat. Int. 77 (3) 482-491. 
Duval, M., Bahain, J.J., Bartz, M., Falgueres, C., Guilarte, V., Moreno García, D., Arnold, L.J., 2017. Defining minimum reporting requirements for ESR dating of optically bleached quartz grains. Ancient TL 35 (1), 11-19.

Falguères, C., Bahain, J.J., 2002. La datation par résonance paramagnétique électronique (RPE). In: Miskovsky, J.C. (Ed.), Geologie de la Préhhistoire. Méthodes, Techniques, Applications, Seconde édition. Géoopré, pp. 1273-1296.

Bahain, J.J., Falguères, C., Voinchet, P., Duval, M., Dolo, J.M., Despriée, J., Garcia, T., Tissoux, H., 2007. Electron Spin resonance (ESR) dating of some European late lower Pleistocene sites. Quaternaire 18 (2), 175-186.

Falguères, C., Sémah, F., Saleki, H., Tu, H., Féraud, G., Simanjuntak, H., Widianto, H., 2016. Geochronology of early human settlements in Java: what is stake? Quat. Int 416, 5-11. https://doi.org/10.1016/j.quaint.2015.10.076.

Ferreira, D.B., 1981. Carte Géomorphologique du Portugal. Memórias do Centro de Est. Geogr. 6.

Figueiredo, P., 2014. Neotectonics of the Southwest Portugal Mainland: Implications on the Regional Seismic Hazard. Univ. Lisboa, pp. 261 (Ph.D. Thesis).

Grün, R., 1994. A cautionary note: use of the water content and depth for cosmic ray dose rate in AGE and DATA programs. Ancient TL 12, 50-51.

Guérin, G., Mercier, N., Adamiec, G., 2011. Dose-rate conversion factors: update. Ancient TL 29, 5-8.

Haywood, A.M., Ridgwell, A., Lunt, D.J., Hill, D.J., Pound, M.J., Dowsett, H.J., Dolan, A.M., Francis, J.E., Williams, M., 2011. Are there pre-Quaternary geological analogues for a future greenhouse warming? Philos. Trans. R. Soc. A Math. Phys. Eng. Sci. 369, 933-956.

Haywood, A.M., Dowsett, H.J., Dolan, A.M., Rowley, D., Abe-Ouchi, A., Otto-Bliesner, B., Chandler, M.A., Hunter, S.J., Lunt, D.J., Pound, M., Salzmann, U., 2016. The pliocene model intercomparison project (pliomip) phase 2: scientific objectives and experimental design. Clim. Past 12, 663-675.

Ikeya, M., 1993. New applications of electron spin resonance dating. Dosimetry and Microscopy Eds Worl Scientific 500.

Jansen, E., Overpeck, J., Briffa, K.R., Duplessy, J.C., Joos, F., Masson-Delmotte, V., Olago, D., Otto-Bliesner, B., Peltier, W.R., Rahmstorf, S., Ramesh, R., Raynaud, D., Rind, D., Solomina, O., Villalba, R., Zhang, D., 2007. Paleoclimate. In climate change, 2007: the physical science basis. In: Solomon, S., Qin, D., Manning, M., Chen, Z., Marquis, M., Averyt, K.B., Tignor, M., Miller, H.L. (Eds.), Contribution of Working Group I to the Fourth Assessment Report of the Intergovernmental Panel on Climate Change. Cambridge University Press, pp. 433-497.

Jiménez-Moreno, G., Fauquette, S., Suc, J.P., 2010. Miocene to Pliocene vegetation reconstruction and climate estimates in the Iberian Peninsula from pollen data. Rev. Palaeobot. Palynol. 162 (3), 403-415.

Jiménez-Moreno, G., Pérez-Asensio, J.N., Larrasona, J.C., Sierro, F.J., Garcia-Castellanos, D., Salazar, A., Salvany, J.M., Ledesma, S., Mata, M.P., Mediavilla, C., 2019. Early Pleistocene climatic optimum, cooling and early glaciation deduced by terrestrial and marine environmental changes in SW Spain. Glob. Planet. Chang. 180, 89-99.

Laurent, M., Falguères, C., Bahain, J.J., Rousseau, L., Van Vliet Lanoé, B., 1998. ESR dating of quartz extracted from quaternary and neogene sediments: method, potential and actual limits. Quat. Sci. Rev. 17 (11), 1057-1062.

Lisiecki, L.E., Raymo, M.E., 2005. A Plio-Pleistocene stack of 57 globally distributed benthic $\delta 180$ records. Paleoceanography 20, PA1003 (17 p).

Loutre, M.F., Berger, A., 2003. Marine Isotope Stage 11 as an analogue for the present interglacial. Glob. Planet. Chang. 36, 209-217.

Martín, J.M., Braga, J.C., Aguirre, J., Puga-Bernabéu, A., 2009. History and evolution of the North Betic Strait (Prebetic Zone, Betic Cordillera): a narrow, early Tortonian tidal-dominated, Atlantic-Mediterranean marine passage. Sediment. Geol. 216, 80-90.

McMorris, D.W., 1971. Impurity color centers in quartz and trapped electron dating: electron spin resonance, thermoluminescence studies. J. Geophys. Res. 76, 7875-7887.

Mercier, N., Falguères, C., 2007. Field gamma dose-rate measurement with a NaI(Tl) detector: re-evaluation of the "threshold" technique. Ancient TL 25 (1), 1-4.

Miller, K.G., Kominz, M.A., Browning, J.V., Wright, J.D., Mountain, G.S., Katz, M.E. Sugarman, P.J., Benjamin, S.C., Christie-Bick, N., Pekan, S.F., 2005. The Phanerozoic record of global sea-level change. Science 310 (1), 293-1298.

Miller, K.G., Mountain, G.S., Wright, J.D., Browning, J.V., 2011. A 180-million-year record of sea level and ice volume variations from continental margin and deep-sea isotopic records. Oceanography 24 (2), 40-53.

Moreno, D., Falgueres, C., Perez-Gonzalez, A., Duval, M., Voinchet, P., Benito- Calvo, A., Ortega, A.I., Bahain, J.J., Sala, R., Carbonell, E., 2012. Bermúdez de Castro, Arsuaga, J.L. ESR chronology of alluvial deposits in the Arlanz on valley (Atapuerca, Spain): contemporaneity with Atapuerca Gran Dolina site. Quat. Geochron 10, 418-423.

Pais, J., 1981. Contribuição para o Conhecimento da Vegetação Miocénica da Parte Ocidental da Bacia do Tejo. Univ. Nova de Lisboa, pp. 328 (Ph.D. Thesis).

Pais, J., 1992. Contributions to the Eocene paleontology and stratigraphy of Beira Alta, Portugal. III - Eocene plant remains from Naia and Sobreda (Beira Alta, Portugal). Ciências da Terra 11, 91-108.

Pais, J., Cunha, P.P., Pereira, D., Legoinha, 2010. Litostratigrafia do Cenozóico de Portugal. In: Neiva, J.M.C., Ribeiro, A., Victor, L.M., Noronha, F., Ramalho, M. (Eds.), Ciências Geológicas: Ensino e Investigação. Associação Portuguesa de Geólogos, Lisboa, pp. 365-376.

Pais, J., Cunha, P.P., Pereira, D., Legoinha, P., Dias, R., Moura, D., Brum Da Silveira, A., Kullberg, J.C., González-Delgado, J.A., 2012. The paleogene and neogene of Western Iberia (Portugal). In: A Cenozoic Record in the European Atlantic Domain. SpringerBriefs in Earth Sciences, 1st edition. 1 vol. Springer, pp. 158 Series ID: 8897.

Panitz, S., Salzmann, U., Risebrobakken, B., De Schepper, S., Pound, M., 2016. Climate variability and long-term expansion of peatlands in Arctic Norway during the late Pliocene (ODP Site 642, Norwegian Sea). Clim. Past 12, 1043-1060.
Pedoja, K., Jara-Muñoz, J., De Gelder, G., Robertson, J., Meschis, M., Fernández-Blanco, D., Nexer, M., Poprawski, Y., Dugu'e, O., Delcaillau, B., Bessin, P., Benabdelouahed, M., Authemayou, C., Husson, L., Regard, V., Menier, D., Pinel, B., 2018. NeogeneQuaternary slow coastal uplift of Western Europe through the perspective of sequences of strandlines from the Cotentin Peninsula (Normandy, France). Geomorphology 303, 338-356.

Prescott, J.R., Hutton, J.T., 1994. Cosmic ray contributions to dose rates for luminescence and ESR dating: large depths and long-term time variations. Radiat. Meas. 23, 497-500.

Ramos, A.M., 2008. O Pliocénico e o Plistocénico da Plataforma Litoral entre os paralelos do Cabo Mondego e da Nazaré. University of Coimbra, pp. 317 (Ph.D. Thesis).

Ramos, A., Cunha, P.P., 2004. Facies Associations and Paleogeography of the Zanclean-Piacenzian Marine Incursion in the Mondego Cape - Nazaré Area (Onshore of Central Portugal). 23rd IAS Meeting of Sedimentology, Abstracts book. pp. 227.

Raymo, M.E., Mitrovica, J.X., O'Leary, M.J., DeConto, R.M., Hearty, P.J., 2011. Departures from eustasy in Pliocene Sea-level records. Nat. Geosci. 4, 328-332.

Ressurreição, R.J.V., 2018. Evolução Tectono-Estratigráfica Cenozóica do Litoral Alentejano (Sector Melides-Odemira) E Enquadramento no Regime Geodinâmico Actual. University of Lisboa, pp. 327 (Ph.D. Thesis).

Ribeiro, P., 1998. Estudo de deformações tectónicas plio-quaternárias no bordo meridional da estrutura diapírica de S. In: Pedro de Moel (Vale de Paredes - Marinha Grande). University of Lisboa (MSc Thesis).

Ribeiro, P., Cabral, J., 1998. Study of Plio-Quaternary tectonic deformations on the Southern side of S. Pedro de Moel diapiric structure (Vale de Paredes - Marinha Grande). Actas do V Congresso Nacional de Geologia (Resumos alargados). Comunicações do Instituto Geológico e Mineiro 84 (I), D-73-D-76.

Rink, W.J., Bartoll, J., Schwarcz, H.P., Shane, P., Bar-Yosef, O., 2007. Testing the reliability of ESR dating of optically exposed buried quartz sediments. Radiat. Meas. 42, 1618-1626.

Rocha, A.T., Ferreira, J.M., 1953. Estudo dos Foraminíferos fósseis do Pliocénico da região de Pombal. Revista da Faculdade de Ciências de Lisboa, $2^{\mathrm{a}}$ Série-C, Vol. III, Fasc. $1^{\circ}$. pp. $129-156$.

Rocoux, K.H., Tzedakis, P.C., de Abreu, L., Shackleton, N.J., 2006. Climate and vegetation changes 180,000 to 345,000 years ago recorded in a deep-sea core off Portugal. Earth Planet. Sci. Lett. 249 (3-4), 307-325.

Rodrigues, T., Voelker, A.H.L., Grimalt, J.O., Abrantes, F., Naughton, F., 2011. Iberian margin sea surface temperature during MIS 15 to 9 (580-300 ka): Glacial suborbital variability versus interglacial stability. Paleoceanography 26, PA1204. https://doi. org/10.1029/2010PA001927.

Rohling, E.J., Foster, G.L., Grant, K.M., Marino, G., Roberts, A.P., Tamisiea, M.E., Williams, F., 2014. Sea-level and deep-sea-temperature variability over the past 5.3 million years. Nature 508 (7497), 477.

Rosina, P., Voinchet, P., Bahain, J.J., Cristovao, J., Falgueres, C., 2014. Dating the onset of lower Tagus River terrace formation using electron spin resonance. J. Quat. Sci. 29 (2), 153-162.

Salzmann, U., Dolan, A.M., Haywood, A.M., Chan, W.L., Voss, J., Hill, D.J., Abe-Ouchi, A., Otto-Bliesner, B., Bragg, M.A., Chandler, C., Contoux, H.J., Dowsett, A., Jost, Y., Kamae, G., Lohmann, D.J., Lunt, S.J., Pickering, M.J., Pound, F., Ramstein, G., Rosenbloom, N.A., Sohl, L., Stepanek, C., Ueda, H., Zhang, Z., 2013. Challenges in reconstructing terrestrial warming of the Pliocene revealed by data-model discord. Nat. Clim. Chang. 3, 969-974.

Silva, C.M., 2001. Gastrópodes Pliocénicos Marinhos de Portugal. Sistemática, Paleoecologia, Paleobiologia, Paleobiogeografia. University of Lisboa, pp. 747 (Ph.D. Thesis).

Teixeira, C., 1979. Plio-Plistocénico de Portugal. Comun. Serv. Geol. Port. 65, 35-46 Lisboa.

Teixeira, C., Zbyszewski, G., 1951. Note sur le Pliocéne de la région à l'Ouest de Pombal. Comunicações dos Serviços Geológicos de Portugal, Lisboa 32 (1), 295-302.

Teixeira, C., Zbyszewski, G., 1954. Contribution à l'étude du littoral Pliocène au Portugal.

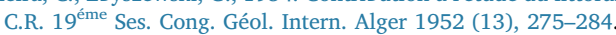

Tissoux, H., Falguères, C., Voinchet, P., Toyoda, S., Bahain, J.J., Despriée, J., 2007. Potential use of Ti-center in ESR dating of fluvial sediment. Quat. Geochronol. 2, 367-372.

Toyoda, S., Falguères, C., 2003. The method to represent the ESR signal intensity of the aluminium hole center in quartz for the purpose of dating. Adv. ESR Appl. 20, 7-10.

Toyoda, S., Ikeya, M., 1991. Thermal stabilities of paramagnetic defect and impurity centers in quartz: basis for ESR dating of thermal history. Geochem. J. 25, 437-445.

Toyoda, S., Ikeya, M., 1994. ESR dating of quartz with stable component of impurity centers. Quat. Sci. Rev. 13 (5), 625-628. https://doi.org/10.1016/0277-3791(94) 90089-2.

Toyoda, S., Voinchet, P., Falguères, C., Dolo, J.M., Laurent, M., 2000. Bleaching of ESR signals by the sunlight: a laboratory experiment for establishing the ESR dating of sediments. Appl. Radiat. Isotopes 52 (5), 1357-1362.

Vieira, M., 2009. Palinologia do Pliocénico da Orla Ocidental Norte e Centro de Portugal: Contributo para a Compreensão da Cronostratigrafia e da Evolução Paleoambiental University of Minho, pp. 389 (Ph.D. Thesis).

Vieira, M., Pound, M.J., Pereira, D.I., 2018. The late Pliocene palaeoenvironments and palaeoclimates of the Western Iberian Atlantic margin from the Rio Maior flora. Palaeogeogr. Palaeoclimatol. Palaeoecol. 495, 245-258. https://doi.org/10.1016/j. palaeo.2018.01.018.

Voinchet, P., Falguères, C., Laurent, M., Toyoda, S., Bahain, J.J., Dolo, J.M., 2003. Artificial optical bleaching of the aluminium center in quartz implications to ESR dating of sediments. Quat. Sci. Rev. 22, 1335-1338.

Voinchet, P., Falguères, C., Tissoux, H., Bahain, J.J., Despriée, J., Pirouelle, F., 2007. ESR dating of fluvial quartz: estimate of the minimal distance transport required for getting a maximum optical bleaching. Quat. Geochronol. 2, 363-366. 
Voinchet, P., Despriée, J., Tissoux, H., Falguères, C., Bahain, J.J., Gageonnet, R., Dépont, J., Dolo, J.M., 2010. ESR chronology of alluvial deposits and first human settlements of the Middle Loire Basin (Region Centre, France). Quat. Geochronol. 5, 381-384.

Voinchet, P., Yin, G., Falguères, C., Liu, C., Han, F., Sun, X., Bahain, J., 2013. ESR dose response of $\mathrm{Al}$ center measured in quartz samples from the Yellow River (China): Implications for the dating of Upper Pleistocene sediment. Geochronometria 40 (4), 341-347.

Voinchet, P., Moreno, D., Bahain, J.J., Tissoux, H., Tombret, O., Falguères, C., Moncel, M.H., Schreve, D., Candy, I., Antoine, P., Ashton, N., Beamish, M., Cliquet, D., Despriée, J., Lewis, S., Limondin-Lozouet, N., Locht, J.L., Parfitt, S., Pope, M., 2015. New chronological data (ESR and ESR/U-series) for the earliest Acheulian sites of
North-Western Europe. J. Quat. Sci. 30 (7), 610-622.

Yokoyama, Y., Falguères, C., Quaegebeur, J.P., 1985. ESR dating of quartz from Quaternary sediments: first attemps. Nucl. Tracks 10 (4-6), 921-928.

Zbyszewski, G., 1943. Eléments pour server à l'étude du Pliocène marin au Sud du Tage: la faune des couches supérieures d'Alfeite. Comunicações dos Serviços Geológicos de Portugal, Lisboa 24, 125-156.

Zbyszewski, G., 1949. Contribution à la connaissance du Pliocène Portugais. Comun. dos Serv. Geol. de Portugal 30, 59-78.

Zbyszewski, G., 1967. Estudo geológico da bacia dos lignitos de Rio Maior. Estudos Notas e Trabalhos do Serviço Fomento Mineiro 17, 5-105. 